CENTRO UNIVERSITÁRIO DE BRASÍLIA (UniCEUB)

PROGRAMA DE INICIAÇÃO CIENTÍFICA

RAQUEL DA SILVA BASTOS

(http://lattes.cnpq.br/5565764319171444)

A TRANSIÇÃO DO GRAFFITI DE MOVIMENTO SOCIAL E
INTERVENÇÃO URBANA PARA ARTE COMERCIALIZADA

Brasília - DF

2020 
RAQUEL DA SILVA BASTOS

(http://lattes.cnpq.br/5565764319171444)

\section{A TRANSIÇÃO DO GRAFFITI DE MOVIMENTO SOCIAL E INTERVENÇÃO URBANA PARA ARTE COMERCIALIZADA}

Relatório final de pesquisa de Iniciação Científica apresentado à Assessoria de Pós-Graduação e Pesquisa.

Orientador: Sávio Tadeu Guimarães (http://lattes.cnpq.br/5125621912157038)

Brasília - DF 2020 


\section{SUMÁRIO}

\section{INTRODUÇÃO}

1.1. Justificativa

1.2. Objetivos

\section{FUNDAMENTAÇÃO TEÓRICA}

2.1. Movimentos sociais e intervenções urbanas

2.2. Transformações do Graffiti: de intervenção pública a encomenda privada

2.2.1 Intenções e interpretações do Graffiti no espaço urbano

2.2.2 Intenções e interpretações Graffiti como produto comercializável

2.3 Contradições atuais: entre transgressão e normatização

2.4 Graffiti em Brasília: estudo de casos

\section{METODOLOGIA}

3.1. Pesquisa de base qualitativa

3.2. Questionário

\section{ANÁLISE}

4.1 Execução dos graffitis e análise da autora

\section{CONSIDERAÇÕES FINAIS}

\section{REFERÊNCIAS BIBLIOGRÁFICAS}

\section{ANEXOS}




\section{Introdução:}

Na pesquisa em questão serão utilizados os termos graffiti e pixação ao invés de grafite e pichação por ser como a comunidade artística se refere ao movimento, mesmo estando gramaticalmente incorreto, por conta do termo usado para se referir aos Writers em Nova York na década de 70.

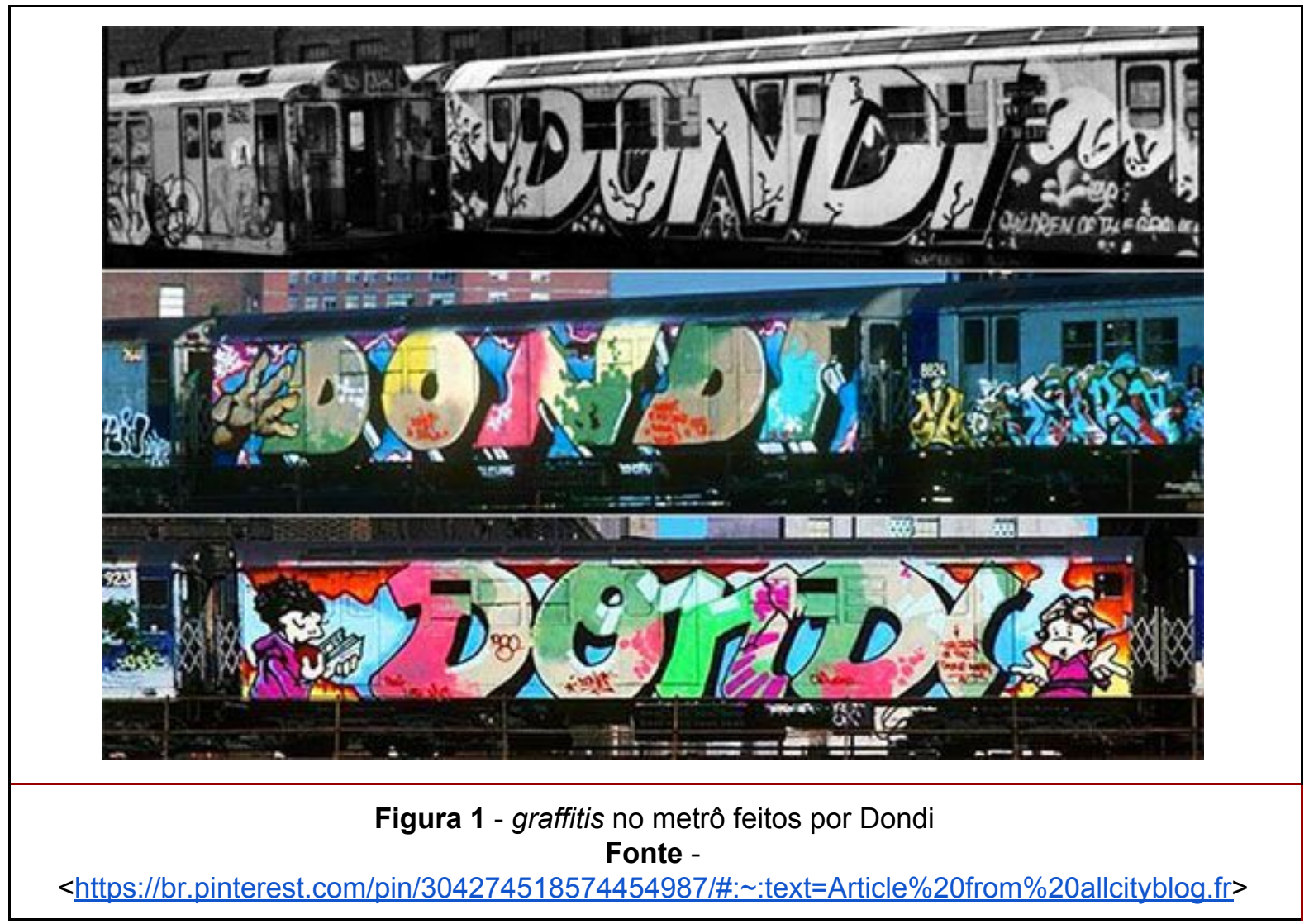

O graffiti é uma expressão artística que faz parte do movimento hip-hop, iniciado nos anos 60 com origem em Nova lorque, por grupos periféricos que utilizavam as artes envolvidas (dj, rap, break dance, graffiti) como agente político e social.

Por consequência do seu surgimento periférico, o movimento foi marginalizado e até criminalizado. No Brasil, em 1998, houve sanção do graffiti pelo art. 65 da Lei $n^{\circ} 9.605$, de 12 de fevereiro que criminalizava o graffiti e pichação podendo resultar em uma multa e detenção de 3 a 12 meses de prisão.

Todavia, em 25 de maio de 2011 foi instituída a Lei $n^{\circ} 12.408$ que alterava o art. 65 da Lei $n^{\circ} 9.605$ descriminalizando o graffiti, uma vez que este fosse realizado com intuito de revitalizar e valorizar o patrimônio público. 
Dessa forma, os artistas tiveram mais liberdade de trabalhar no espaço urbano, ganhando popularidade entre as pessoas a ponto de ser consumido e comercializado por indivíduos de diferentes motivações e classes sociais. O que resulta em opiniões distintas acerca do assunto, quando se trata do espaço público e privado e sobre a intenção artística do grafiteiro.

Portanto, com base no exposto acima, a presente pesquisa visa mostrar os diferentes pontos de vista de vários agentes envolvidos por essa arte (grafiteiros, críticos de arte e o público em geral) para melhor refletir e compreender sobre como artistas dessa modalidade de expressão mantém sua visão artística após a ocupação do espaço privado mediante a trabalhos encomendados.

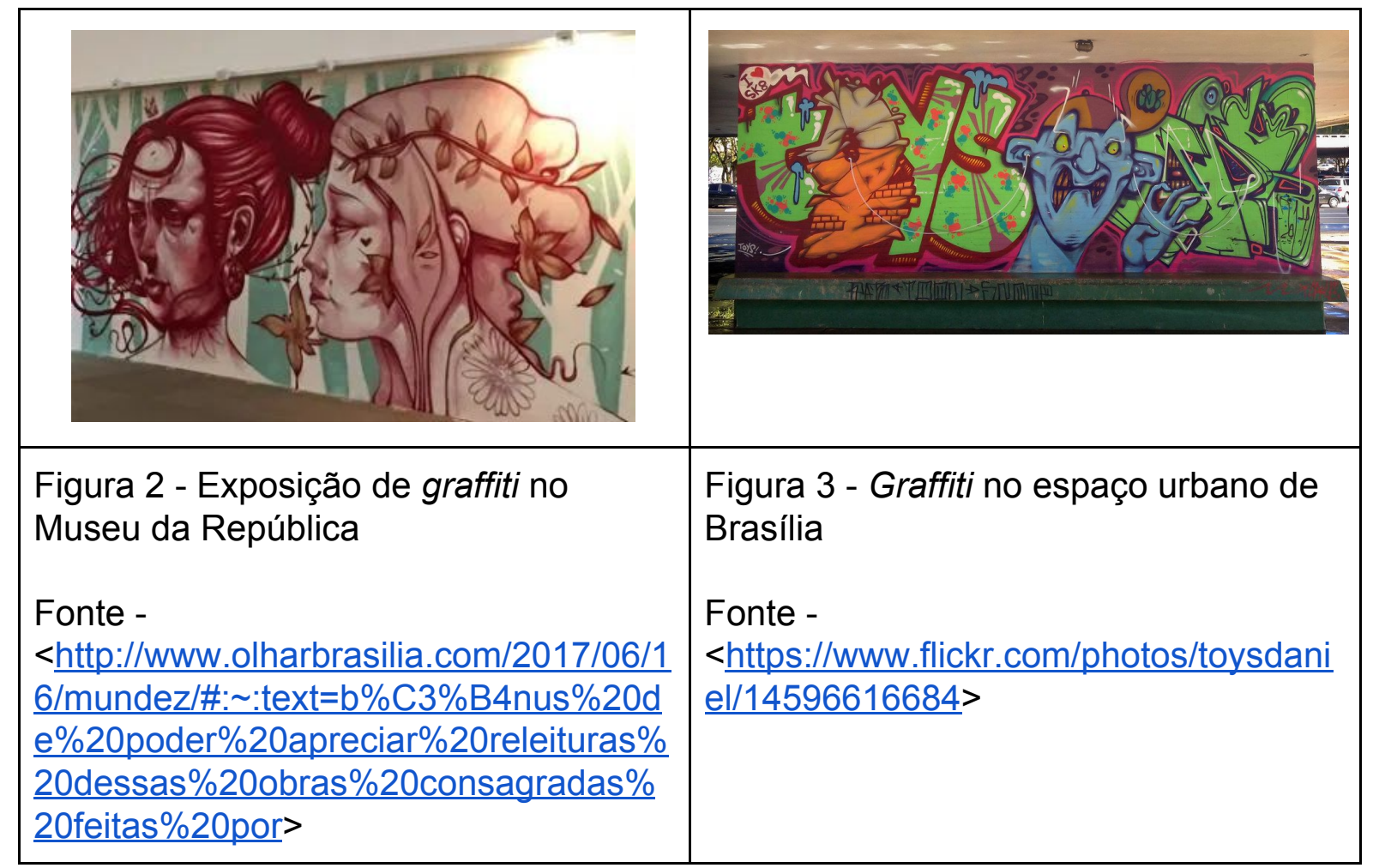

\section{OBJETIVOS}

Objetivo Geral:

. Realizar uma pesquisa comparativa sobre a percepção de distintos grupos de indivíduos em relação às intervenções realizadas no espaço público e privado por meio das expressões em graffiti. 
Objetivos específicos:

- Realizar alguns objetivos específicos tais como a construção de um banco de imagens sobre graffiti no exterior e no Brasil, com foco em Brasília - material a ser anexado no pesquisa finalizada;

- Realizar a criação de um banco de dados sobre a percepção do grafitti por grupos distintos de atores a partir das entrevistas realizadas sob a pauta de um questionário base - material a ser anexado no pesquisa finalizada;

Desenvolver 4 grafittis na cidade de Brasília, em espaços diversos ( tanto de caráter público quanto privado ) que poderão permanecer em tais espaços após a realização da pesquisa.

\section{JUSTIFICATIVA}

Como artista da área, posso observar a diferença da percepção de cada indivíduo em relação ao graffiti mediante a esfera que ele está inserido. $O$ ambiente público, como Hannah Arendt cita em seu livro "A Condição Humana", é incapaz de abrigar o irrelevante, dessa forma podemos concluir que uma intervenção urbana como o graffiti pode ser despercebido no dia a dia das pessoas.

Entretanto, quando se trata de graffitis monumentais, estes podem ser assimilados como gentilezas urbanas e pontos de referência, o que pode ser comprovado uma vez que um dos artistas de graffiti brasileiros mais reconhecidos é o Kobra e suas artes são extremamente prestigiadas mundialmente.

Já no meio privado, o graffiti instantaneamente é associado às artes plásticas o que valoriza a arte, mas não contribui a discussão ideológica que o graffiti carrega em sua origem, consequentemente o ser humano é privado da realidade da obra.

Dessa forma, as opiniões sobre o graffiti se divergem no que tange a esfera pública e privada gerando assimilações e opiniões diversas sobre as intenções artísticas do artista assim como da obra em questão e, de certa forma, essas opiniões têm um grau de influência na produção artística dos grafiteiros que se pretende analisar por meio desse projeto de pesquisa aqui proposto. 


\section{Fundamentação Teórica:}

\subsection{Movimentos sociais e intervenções urbanas}

O graffiti diverge opiniões sobre sua origem, para explicar essa divergência necessário identificar o graffiti de duas formas, a primeira como ato de se comunicar e a segunda de transgredir, as duas definições podem ser complementares. Se classificarmos como comunicação, o graffiti teria seus primeiros registros na préhistória, já se classificarmos como transgressão o grafite tem seus primeiros registros em 1942 com um artista chamado KILROY, este participou da Segunda Guerra e virou uma celebridade após escrever em suas bombas "KILROY WAS HERE" (figura 4) mas foi nos anos 70 que o graffiti ganhou força na cena americana, especialmente em Nova lorque onde jovens marcavam a cidade com graffitis, personagens ou letras.

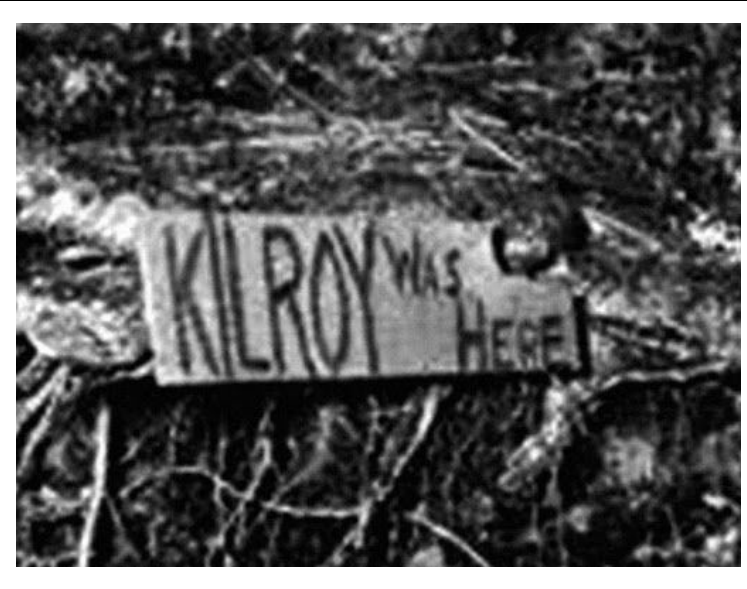

Figura 4 - "KIROY WAS HERE"

Fonte -

<http://besidecolors.com/kings-of-graffiti-kilroy/\#: :text=Kings $\% 20$ of $\% 20$ Graffiti $\% 2$ 0\%E2\%80\%93\%20Kilroy>

Apesar de haver registros de manifestações que podem ser consideradas como graffiti a palavra foi usada como definidora do movimento pela primeira vez no manual de conduta dos metrôs de Nova lorque, de uma forma depreciativa que a 
mídia adotou para se referir ao movimento artístico, antes disso os artistas do graffiti eram denominados como writers.

Os metrôs de Nova lorque eram muito visado pelos writers uma vez que seus trabalhos circularam por toda a cidade. Essa era o objetivo do writer ter seu trabalho visto em todos os lugares, por mas que as pessoas não entendessem, era uma comunicação entre os artistas, uma cultura voltada para ela mesma, como podemos observar no documentário Style Wars (1983).

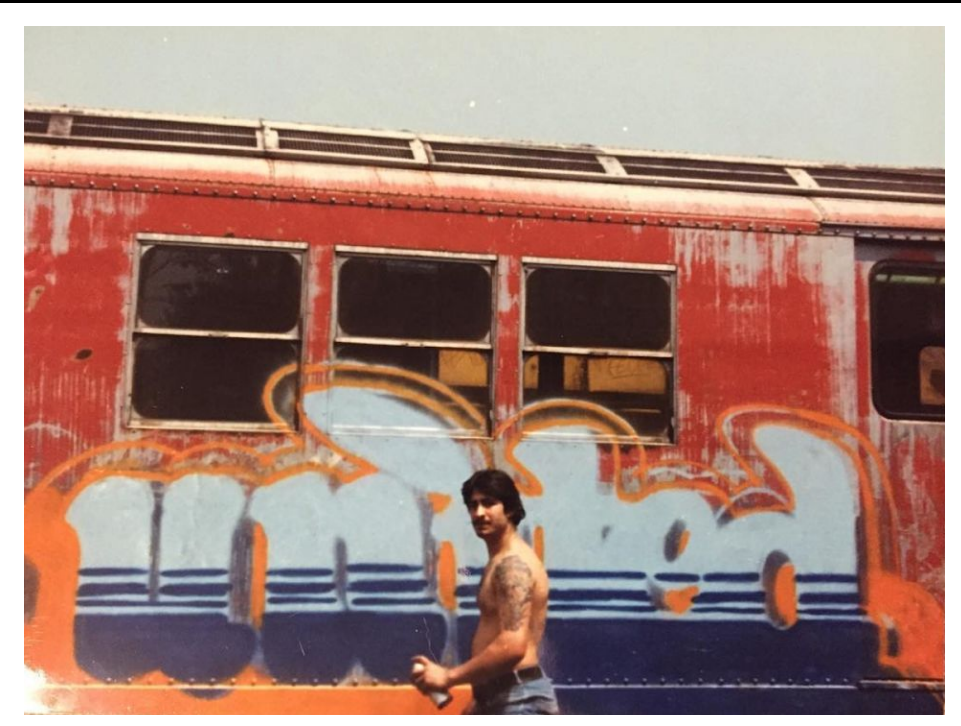

Figura 5 - Grafiteiro SEEN pintando vagão de mêtro

Fonte -

<http://besidecolors.com/kings-of-graffiti-seen/\#: : text=se $\% 20$ dedicar $\% 20 a 0 \% 20 \mathrm{~m}$ undo $\% 20$ das $\% 20$ galerias $\% 20$ de $\% 20$ arte. $\% 20$ Em $\% 20$ sua $>$

A partir de então esse fenômeno de ocupar o espaço urbano foi se popularizando tanto pelo sentido comunicacional como pelo ato de transgredir passando a ocupar não apenas o espaço público como o privado e ganhando cada vez mais relevância cultural.

2.2 Transformações do Graffiti: de intervenção pública a encomenda privada 
O graffiti ao ser inserido no processo de globalização deixou de ser apenas um fenômeno local e passou a ser um fenômeno global. O que antes era uma expressão artística limitada ao local e ao conhecimento de um grupo limitado de pessoas hoje é mundialmente reconhecida.

Entretanto, há um problema em encontrar definições universalizantes devido seu caráter mutável logo, nos subitens abaixo será exposto reflexões acerca de fatores que influenciam na produção e comercialização do grafite, assim como os agentes envolvidos os artistas, consumidores e patrocinadores da arte.

\subsubsection{Intenções e interpretações do graffiti no espaço urbano}

Para conhecer a cultura que envolve o graffiti é conveniente adotar a "deriva", uma técnica situacionista de andar sem rumo pela cidade, desse jeito o espectador poderá perceber como a arte ocupa a cidade e interage com o meio urbano, como Massacci diz em seu livro "A cidade polifônica", "não somos espectadores urbanos, mas sim atores que continuamente dialogamos com seus muros"(Canvacci,1993, p.22). Dentro desse diálogo há três agentes comunicadores: o produtor da arte, o público e o patrocinador da arte.

Para o produtor da arte urbana, o espaço urbano é visto como uma tela, como o fotógrafo "Choque" diz no documentário Pixo (2010) que a pixação segue as linhas guias da cidade e a cidade de São Paulo se tornou um agente verticalizador das letras, o que também é aplicável ao graffiti , a arte procura ocupar os espaços urbanos seja de forma vertical ou horizontal, acompanhando o traçado urbano da cidade. 


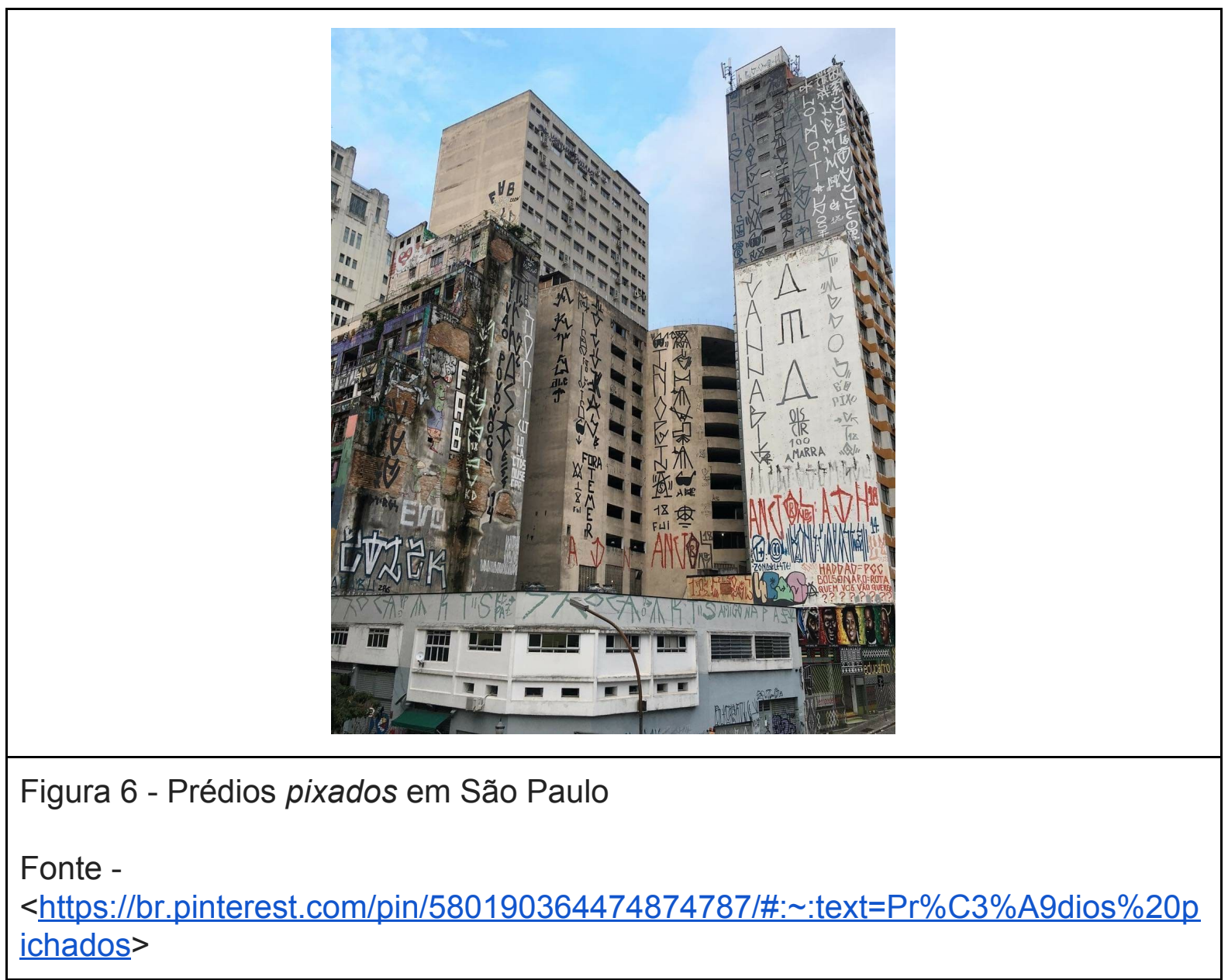

Dentro desses espaços explorados pelos grafiteiros e pixadores há uma hierarquia de lugares a serem pintados, o chamado "pico" é o lugar de maior prestígio que os artistas pintam, no caso são prédios muito altos, lugares arriscados ou com alto fluxo de pessoas que tornam o autor da arte respeitado por outros artistas. O "pico" é o ponto máximo de interesse para os artistas que buscam a transgressão, o que o torna um lugar muito visado pelos artistas, mas não tem a mesma importância para os consumidores, que por sua vez podem reparar no trabalho por ser em um lugar muito exposto, mas não darão a mesma importância que o artista para o grau de transgressão da obra.

Dessa forma, o público da arte pode enxergar o diálogo entre o graffiti e o espaço urbano de duas formas, a primeira o graffiti se torna um agente de "gentileza urbana", termo usado por Jaime Lerner (Acupuntura Urbana, 2003, p.27) para descrever um tipo de "acupuntura urbana", que seria uma ação tomada pelo cidadão para contribuir com a melhora da cidade, apesar de que este conceito vai de 
encontro com a ideia de transgressão que está presente na origem do graffiti, logo podemos concluir que a visão do espectador e consumidor da arte nem sempre coincide com a motivação do artista.

A segunda forma de enxergar esse diálogo é tomando público o como incapaz de abrigar o irrelevante (Arendt, 1958, p. 78), o caráter efêmero e mutável do graffiti faz com que a arte torne-se despercebível na escala urbana da cidade, uma vez que os espaços escolhidos pelos artistas para intervir nem sempre são pontos focais da cidade, além de não haver manutenção das obras que muitas vezes vão se aglomerando com outros elementos urbanos como propagandas, até mesmo depredação da arte por conta de rixas entre artistas.

Já para o patrocinador a encomenda do trabalho se dá por duas razões, a primeira, com o intuito de revitalizar ou reformar o exterior de suas propriedades e a segunda , o pela contemplação da arte, o patrocinador leva em conta as intenções do artista e por esse motivo encomenda suas artes.

\subsubsection{Intenções e interpretações Graffiti como produto comercializável}

O graffiti surge como arte mutável, um produto da sociedade líquida descrita por Bauman, de modo que o rearranjo social resultante da modernidade levou o graffiti a ser contemplado em novos espaços de exposição e por públicos diversos, sobre o possível público do graffiti Ricardo Campos discorre:

Uma das questões que se colocam com mais frequência e cuja resposta não é evidente, é a seguinte: «quem é o público das mensagens que encontramos nos muros da cidade?» Aparentemente, o público do graffiti não é muito diferente daquele a que se dirigem as mensagens publicitárias. Ou seja, pretende chegar a todos, embora só alguns se sintam verdadeiramente inspirados ou tocados por aquilo que vêem e lêem (CAMPOS, 2007, p. 256).

Com o advento das redes sociais surge a possibilidade de enxergar o irrelevante, não é mais necessário estar presente no local da arte para haver contemplação, dessa forma o graffiti foi se popularizando e alcançando pessoas de diversas classes sociais que passaram a almejar não só a arte como o estilo de vida do artista urbano e seu caráter transgressor.

Por conta da popularização do graffiti, as pessoas passaram a encomendar trabalhos em espaços privados, entretanto conforme Hannah Arendt cita em seu 
livro A condição Humana (1958) o privado limita a perspectiva do homem, apesar do espaço de exposição privado agregar valor comercial a obra, este não colabora com a discussão ideologia presente na origem do graffiti, sobre a transgressão praticada pelo graffiti.

Todavia a comercialização do graffiti dividiu as opiniões dos artistas. Há grafiteiros que afirmam que os trabalhos pagos não tem a essência do graffiti, há uma perda de identidade.

Por trás do culto da liberdade pregado pela modernidade líquida, existem inúmeras ditaduras, como essa, a qual altera de forma substancial o pensar e o agir das pessoas, distorcendo a realidade e construindo uma hiper-realidade caracterizada pela perda do referencial de identidade, atendendo a uma imposição econômico-cultural (BAUMAN, 1999,p. 51).

Para os artistas é como uma forma de alienação, Guy Debord em seu livro $A$ Sociedade do Espetáculo (2003) afirma que quanto mais a vida é transformada em mercadoria mais o indivíduo se separa dela, ou seja, quanto mais o indivíduo comercializa o graffiti mas ele se distancia do objetivo original de transgredir os espaços.

Já para os consumidores, o valor sígnico do graffiti é de rebeldia, ao consumir a arte a intenção é assumir essa característica, esse estilo de vida que vem sendo cada vez mais difundido por festas que celebram o hip-hop que não são necessariamente para a comunidade que produz a cultura hip-hop.

\subsection{Contradições atuais: entre transgressão e normatização}

As questões legais que envolvem o graffiti se mostram contraditórias assim como a reação de determinadas entidades e instituições. No Brasil, em 1998, houve sanção do graffiti pelo art. 65 da Lei $n^{\circ} 9.605$, de 12 de fevereiro que criminalizava o graffiti e pixação podendo resultar em uma multa e detenção de 3 a 12 meses de prisão. Todavia, em 25 de maio de 2011 foi instituída a Lei n ${ }^{\circ} 12.408$ que alterava o art. 65 da Lei $n^{\circ} 9.605$ descriminalizando o graffiti, desde que o mesmo fosse autorizado. Na prática não houve mudanças, a realização da arte só está 
resguardada se alguém com autoridade autorizar, o que antes da Lei $n^{\circ} 12.408$ já era uma realidade.

Nesse panorama, podemos observar casos de contradições envolvendo principalmente instituições e artistas. O primeiro caso aqui evidenciado é o da estação ferroviária da cidade paulista de Assis, que foi desativada em 1999 e em 2014 sofreu uma revitalização da fachada pelo artista Alemão, a intenção do artista era chamar atenção da população e dos governantes para o patrimônio histórico que estava deteriorado. Ele conseguiu realizar seu objetivo, entretanto a prefeitura não restaurou o prédio como o artista estava reivindicando. A prefeitura apenas cobriu os graffitis com a cor original da estação, mas não houve um projeto de restauração do patrimônio. Na prática o prédio continuou deteriorado, mas com uma pintura nova.

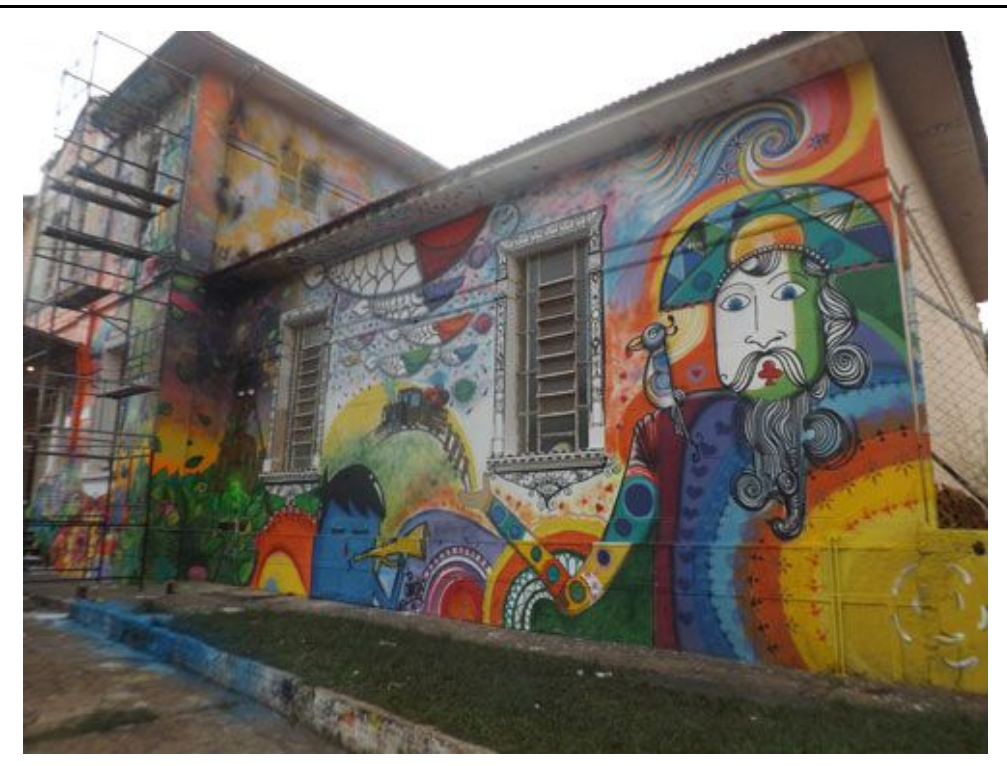

Figura 7 - Estação ferroviária de Assis

Fonte -

$<$ https://www.assiscity.com/local/artista-pede-doacao-de-material-para-terminar-gr afite-na-estacao-ferroviaria-de-assis-34201.html>

O segundo caso é o de Rafael PixoBomb, aluno bolsista da belas artes que foi jubilado após pixar a faculdade belas artes para o seu trabalho de conclusão de curso, a instituição jubilou tal artista que recebia bolsa justamente por conta de suas 
pixações, mas sua manifestação artística na belas artes foi vista como depredação do espaço da faculdade, conforme artigo "Pixação como trabalho de conclusão de curso (TCC):Corajosos investimentos filosóficos para o ensino da arte" Gustavo Coelho - UERJ 2009

As linguagens do graffiti e do pixo passaram a integrar o repertório da arte contemporânea, mas isso não elimina as tensões que a pixação indevida gera no espaço urbano. Justamente pelo caráter transgressor, os pixadores desempenham papel importante na investigação dos limites artísticos. Carlos Zibel, citado por Christina Queiroz (ed. 269,2018).

A atitude de Rafael cumpriu com seu propósito transgressor que é definidor da arte, entretanto a faculdade não reconheceu o ato do artista como arte e sim como violação do espaço da faculdade.

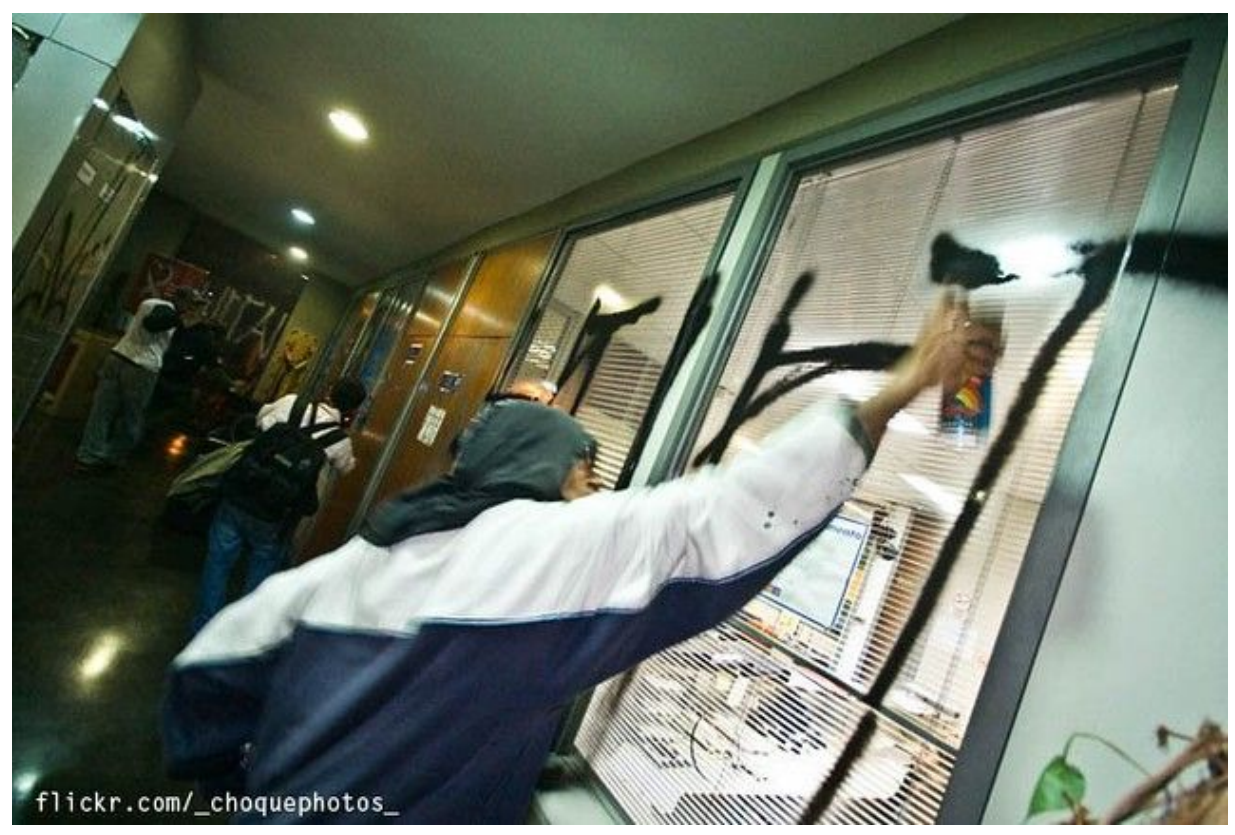

Figura 7 - Homem fazendo uma pixação na Belas Artes

Fonte - <https://www.flickr.com/photos/pixoartatack/4604135933>

O terceiro caso foi o da $29^{a}$ Bienal de São Paulo, que chamou os artistas que invadiram a $28^{a}$ Bienal de São Paulo e pixaram os espaços vazios de forma ilegal, mas dessa vez eles foram chamados para rodas de conversas e documentações como fotos, a prática da arte não foi incentivada, já que os pixadores não podiam usar as latas de spray ou qualquer material para pintar nas paredes, como podemos 
conferir na matéria de Tomaz para o g1 "Após invasão em 2008, pichadores são convidados a voltar à Bienal".

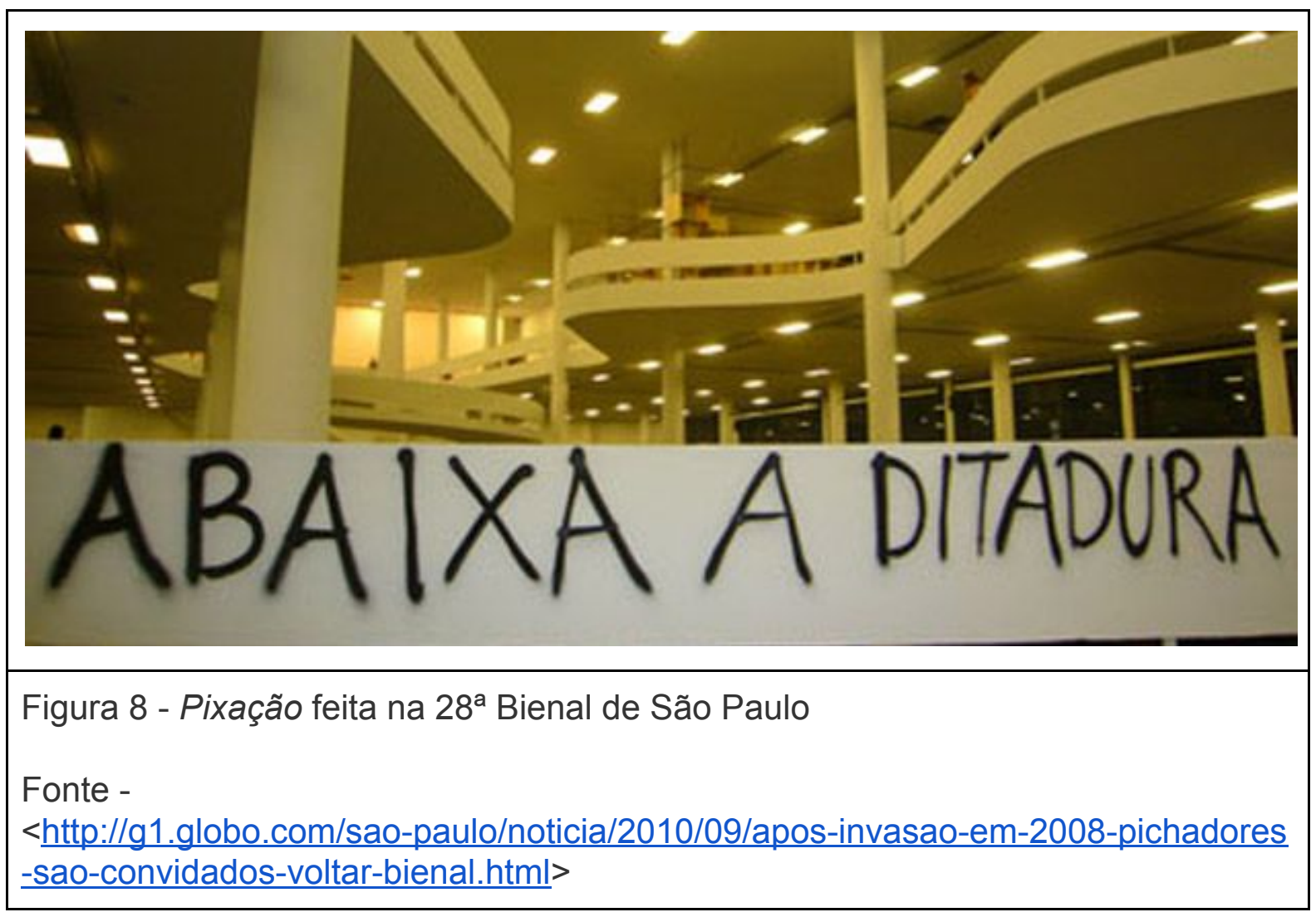

O quarto caso é o dos painéis da 23 de Maio (São Paulo), no documentário Cidade Cinza (2013) pode-se observar o posicionamento da prefeitura contra intervenções urbanas, na gestão do Kassab houve a contratação de um grupo terceirizado para cobrir com tinta cinza o que seriam os trabalhos "ilegais" dos artistas, mas fica evidente que a empresa contratada cobre os graffitis e pixações de forma arbitrária, conforme eles acham que o trabalho é bonito ou não. Nesse contexto os graffitis da avenida 23 de Maio que haviam sido pintados em $2002 \mathrm{com}$ dinheiro arrecadado foram apagados mais de $700 \mathrm{~m}^{2}$ de obras de artistas como Nina Pandolfo, Herbert Baglione e Vitché, OS GÊMEOS. Com o apoio da mídia os artistas que haviam pintado em 2002 foram chamados de volta para pintar novamente o paredão, mas mesmo após a inauguração o prefeito manteve a mesma política pública de "limpar a cidade" que continuou em vigor na regência de Fernando Haddad. 


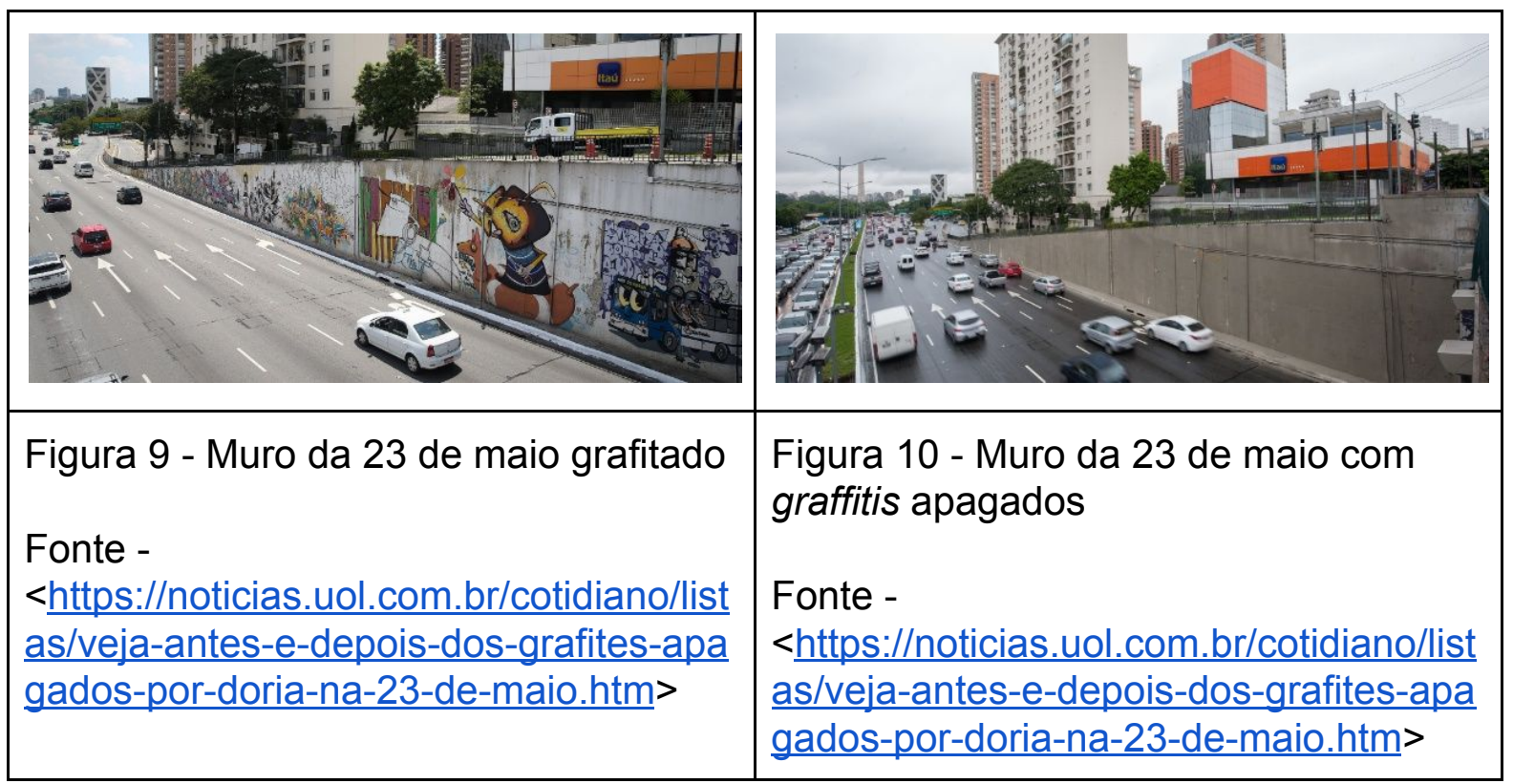

Mesmo com toda a repercussão negativa sobre o mural de 2002 ter sido apagado, em 2017 a gestão de João Dória voltou a apagar os graffitis da 23 de Maio alegando que estes estavam degradados por conta de pixações, entretanto João Doria tomou essa atitude sem consultar os artistas do mural se eles gostariam de fazer um restauro do mural, tal gestão apagou as artes e delimitou onde seriam as novas artes além de implementar um paredão verde com mais de $6 \mathrm{~km}$ que não houve manutenção e ficou com várias partes degradadas. Apesar de sua atitude ter sido repreendida pela justiça e o mesmo ter que pagar uma indenização de $\mathrm{R} \$$ 782.300 percebe-se que a prefeitura de São Paulo está a duas décadas em conflito com grafiteiros e pixadores, o que é uma grande contradição visto que São Paulo é uma das cidades com mais intervenções urbanas do mundo, é um ponto turístico para apreciadores da arte do mundo todo.

Outra ação des gestão da Prefeitura de São Paulo que gera vários questionamentos foi a sanção do projeto de lei que pune pixadores e grafiteiros com multas que variam entre $R \$ 5$ mil e $R \$ 10$ mil. A lei foi feita para inibir os pixadores e grafiteiros sem autorização, desconsiderando completamente o caráter transgressor do graffiti, essa atitude não leva em conta a origem do graffiti, o que se torna uma ironia considerando que o dinheiro da multa vai para o Fundo de Proteção ao Patrimônio Cultural que deveria resguardar o graffiti e sua origem como movimento 
contemporâneo de arte. Outra contradição é que o Fundo de Proteção ao Patrimônio Cultura é o mesmo órgão que recebeu a indenização paga por essa gestão da administração municipal da cidade por ter apagado os graffitis da 23 de Maio.

\subsection{Graffiti em Brasília: estudos de caso}

Devido a configuração urbana de brasília, o graffiti dialoga com o espaço urbano de forma distinta a outras cidades. Seu perfil urbano horizontalizado torna os "picos" em edifícios em altura impraticáveis, por consequência disso um dos maiores "pico" do Plano Piloto se tornou o Buraco do Tatu, que em outra cidade possivelmente seria negligenciado por estar no subsolo, mas em brasília se tornou um dos ponto de intervenção mais almejado por grafiteiros e pixadores.

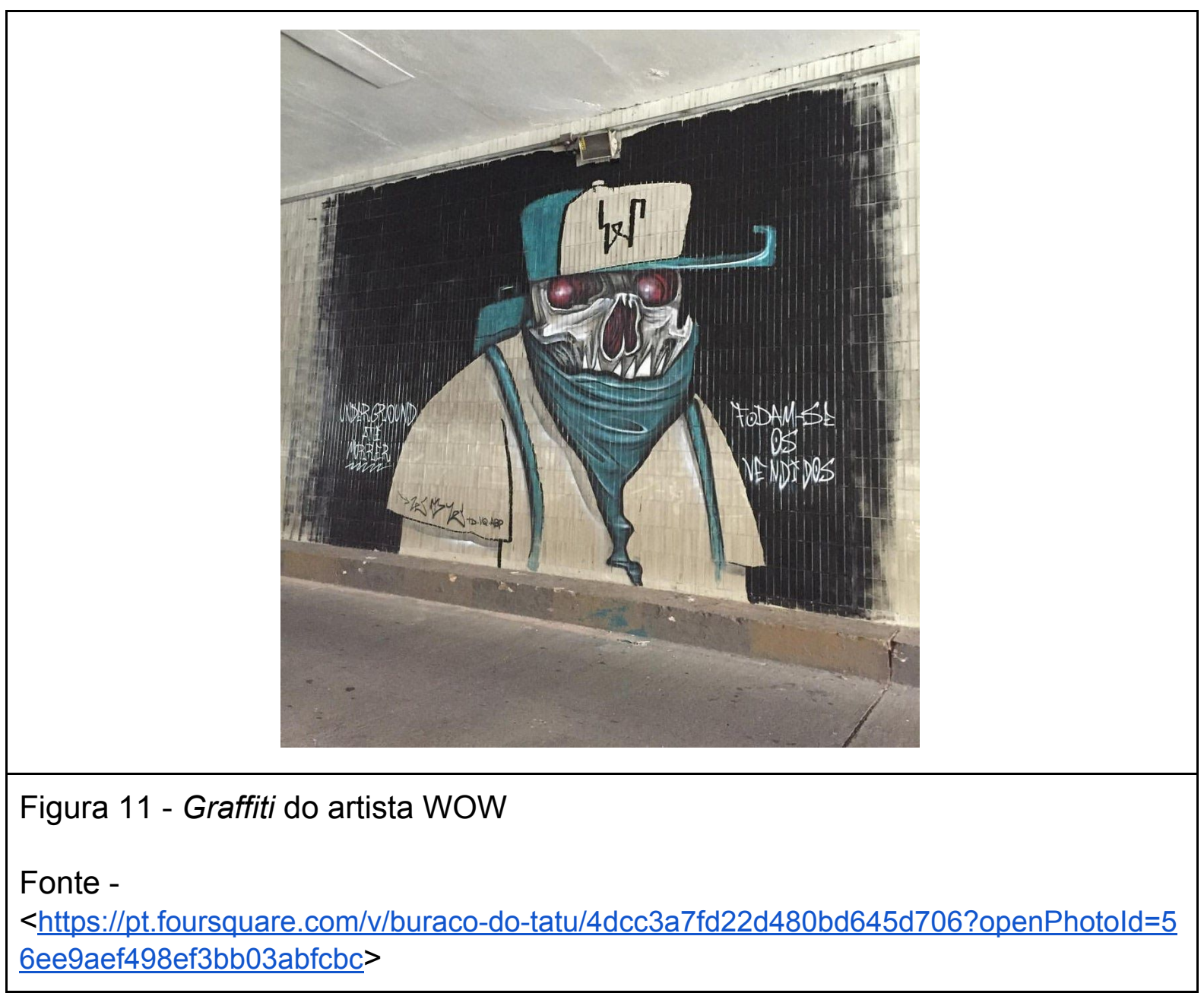


Outra característica urbana de Brasília que influencia a cultura do graffiti é a presença de grandes espaços vazios que é descrito por Bauman como "brasilite":

Para seus moradores, porém, Brasília revelou-se um pesadelo. Logo foi cunhado por suas infelizes vítimas o conceito de "brasilite", nova síndrome patológica de que Brasília era o protótipo e o mais famoso epicentro até então. Os sintomas mais notáveis de "brasilite", na opinião geral, eram a ausência de multidões e ajuntamentos, as esquinas vazias, o anonimato dos lugares, as figuras humanas sem rosto e a entorpecente monotonia de um ambiente desprovido de qualquer coisa que intrigasse, excitasse ou causasse perplexidade (BAUMAN, 1999, p. 51).

Esses espaços vazios se tornaram lugares que os artistas utilizam para a melhorar sua técnica, mas sem visibilidade, irrelevantes para os consumidores da arte, como o setor comercial. Também há espaços que são impraticáveis a realização da arte, como a esplanada pela ausência de muros.

O terceiro aspecto urbano de brasília que é relevante para a prática do graffiti é o tombamento da cidade, que prevê pelo artigo $2^{\circ}$ Portaria $n^{\circ} 314$, de 08 de outubro de 1992 a manutenção das características essenciais das quatro escalas urbanas de brasília o que torna o graffiti mesmo que autorizado um elemento depravador do patrimônio histórico que é brasília.

Apesar disto, a Secretaria da Cultura promove editais que apoiam os artistas de urbanos, entre esses incentivos estão o projeto Obra a Frente que formulou uma plataforma que conecta os habitantes que querem ter o exterior de suas propriedades pintados, e artistas que estão a procura de espaços urbanos para intervir com seu trabalho.

Outro projeto apoiado pela Secretaria da Cultura foi a renovação das fachadas do Espaço Cultural Renato Russo, foram convocados diversos artistas urbanos entre eles nomes como Toys, Omik, Siren, Guga Baygon, Soneka, Brixx, Borgê, Atoa, Derk, todos artistas brasilienses.

Esses editais surgiram após a movimentação dos artistas contra a Lei Distrital $n^{\circ}$ 6.094/2018 que punia grafiteiros e pixadores no valor de cinco a dez mil reais caso pintassem sem autorização. Em torno de 50 grafiteiros e grafiteiras se reuniram e apresentaram contra propostas em relação a lei e com isso fizeram um 
decreto de valorização do graffiti o Decreto 39.174/2018, neste prevê um encontro de graffiti por ano. Desde então houveram 3 encontros, o primeiro nas entradas do parque da cidade, o segundo na comunidade do sol nascente e o terceiro no setor comercial sul.

\section{Metodologia:}

\subsection{Pesquisa de base qualitativa}

As entrevistas possuem papel de relevância na elaboração de uma pesquisa para a formação de uma base qualitativa,"A entrevista qualitativa, pois, fornece os dados básicos para o desenvolvimento e compreensão das relações entre os atores sociais e suas situação."(GASKELL, 2002, p.65) Na pesquisa em questão será aplicado três formulários diferentes para três agentes distintos (artistas, apreciadores e consumidores) a fim de levantar dados acerca das opiniões distintas que existem sobre o graffiti e seu universo.

Dessa forma poderemos analisar em que pontos as opiniões dos atores distintos entram em concordância ou não, e como essas opiniões influenciam na formação de um senso sobre o graffiti e o espaço urbano. "O objetivo é uma compreensão detalhada das crenças, atitudes, valores e motivações, em relação aos comportamentos das pessoas em contextos sociais específicos" (GASKELL, 2002, p.65).

\subsection{Questionário}

A partir dessas premissas da pesquisa de base qualitativa, foram elaborados entrevistas específicas para cada um dos três grandes grupos identificados no estudo como os mais vinculados ao objeto de estudo e passíveis de entregar respostas aos questionamentos lançados inicialmente e que direcionaram as investigações. Esses três grandes grupos de atores, os artistas urbanos, os patrocinadores de suas obras e consumidores de suas obras, foram entrevistados tendo como base as específicas entrevistas apresentadas no apêndice da pesquisa. esses três questionários não foram utilizados posteriormente quando se decidiu 
fazer as entrevistas virtualmente e, nesse caso, uma entrevista única foi considerada mais produtiva para sua difusão virtual. Esse questionário único, que contém perguntas gerais e específicas para os três grandes grupos identificados no estudo, é apresentado abaixo:

1 - Ao percorrer caminhos urbanos, você percebe intervenções urbanas presentes na cidade?

2 - Que tipo de intervenções artísticas você se lembra ter visto? Alguma delas te chamou mais atenção?

3 - Na sua opinião, qual é a principal motivação de um artista para intervir em um espaço público?

4 - Na sua opinião, qual é a principal motivação de um artista para intervir em um espaço privado?

5- Para você, o que representam as intervenções realizadas por meio do graffiti?

- arte, atividade de caráter social, comunicação, publicidade, poluição visual, crime

6 - Para você, existe diferença entre graffiti e pixação?

7 - E quanto a pixação, o que ela representa para você?

- arte, atividade de caráter social, comunicação, publicidade, poluição visual, crime

8 - Você acha que o local de exposição de uma obra de arte agrega valor a ela?

9.a- Este graffiti foi realizado em um espaço público. Você acha que ele teria a mesma assimilação visual se estivesse em um lugar privado?

9.b- Este graffiti foi realizado em um espaço público. Você acha que ele teria a mesma assimilação visual se estivesse em um lugar lugar privado?

10.a- Este graffiti foi realizado em um espaço privado. Você acha que ele teria a mesma assimilação visual se estivesse em um lugar público?

10.b- Este graffiti foi realizado em um espaço privado. Você acha que ele teria a mesma assimilação visual se estivesse em um lugar público?

11 -Qual a sua relação com graffiti?

- Pratico grafite, Já encomendei o trabalho de um grafiteiro para o meu espaço privado, Apenas um observador (podendo gostar ou não da prática) 
12 - Para você, o graffiti tem potencial para dar uma nova identidade ao local onde é realizado? Se sim, de que maneira. (Pergunta específica para pessoas que observam o graffiti no espaço público ou privado.)

13 - Você acha que o graffiti agrega valor comercial ao local? Se sim, de que maneira?(Pergunta específica para pessoas que já encomendaram um graffiti para seu espaço privado. (Caso não se enquadre no grupo responder "SR")

14- Você conhece legislações em relação às intervenções realizadas por meio de graffiti ou pixação? Se sim, identifica contradições em alguma norma especifica?(Pergunta específica para grafiteiros. (Caso não se enquadre no grupo responder "SR")

15- Você conhece incentivos públicos para intervenções realizadas por meio de graffiti? Se sim, quais?(Pergunta específica para grafiteiros. (Caso não se enquadre no grupo responder "SR")

\section{Análise:}

\subsection{Execução dos graffitis e análise da autora}

Ao executar os graffitis foi observado pela autora que os graffitis não podem ser categorizados apenas por públicos e privados, mas sim pela sua influência no espaço que os abrangem, dessa forma foram avaliados não apenas os graffitis propostos na metodologia, mas sim todos os graffitis realizados pela autora no período da pesquisa, dentre esses estão graffitis feitos sem autorização, graffitis realizados e eventos públicos e privados.

Graffitis no espaço público não autorizados

Os graffitis foram realizados em Brasília e São Paulo em espaços não autorizados, esses graffitis foram feitos rápido sem preocupação com a estética, mas sim com a exibição do "vulgo" do grafiteiro, seu nome artístico. A motivação do 
artista é ocupar o espaço urbano, gerar uma comunicação fechada entre os artistas ou consumidores da cultura hip hop e ter seu "vulgo" visto pelo máximo de pessoas possível, elas gostando do seu trabalho ou não.

A imagem 12 é um throw ups que são graffitis que como o nome diz, são "vomitados", é a letra com o nome do vulgo feita de qualquer jeito, essas letras são feitas em média de um minuto ou até menos, a figura 13 é um graffiti outline, ou seja, só feito com a linha sem preenchimento. Já as imagens 14 e 15 são tags, o vulgo do artista é feito com marcadores ou canetas, em geral pode-se encontrar essas intervenções em portas, banheiros, orelhões, postes, paradas de ônibus e em ônibus.

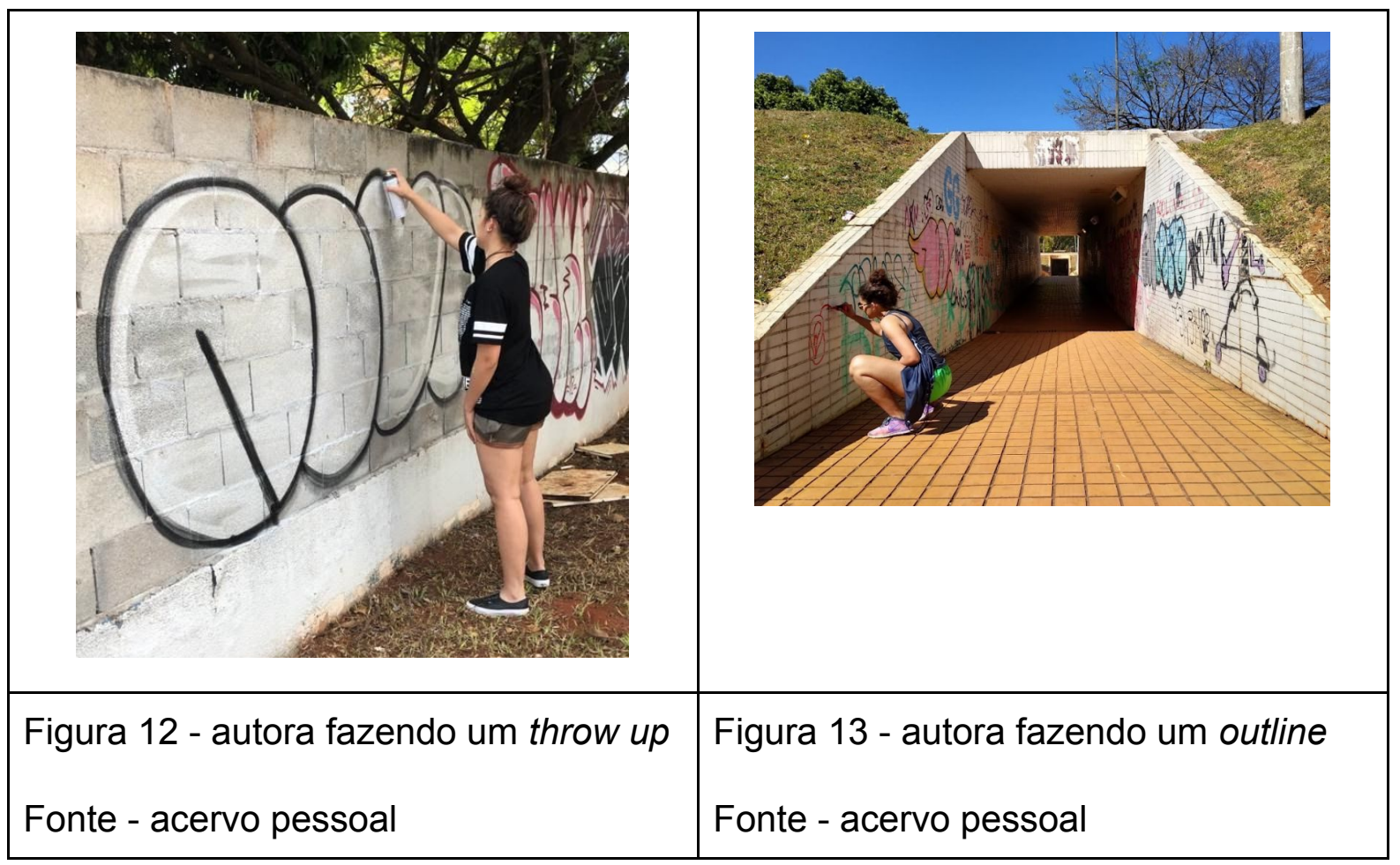




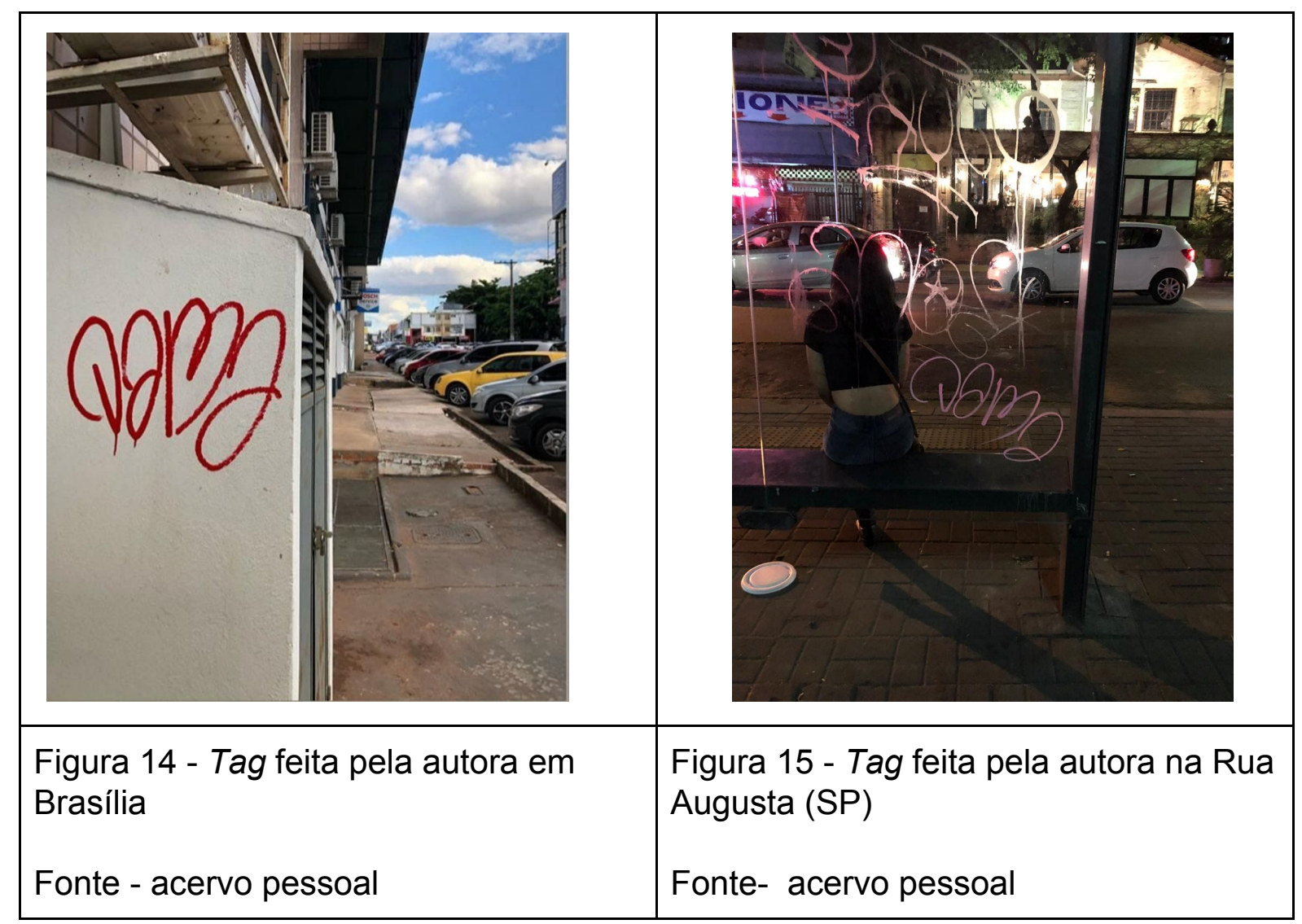

\section{Graffiti na fachada do café Antonieta}

Esse graffiti foi realizado na fachada do café antonieta na Asa Norte, pela autora e pelo grafiteiro Mudof. A autora fez contato com a dona do café e a mesma autorizou. Nesse processo a autora entrou em contato com síndicos de quadras residenciais da asa norte para pintar no "bloco" da ceb localizado nas quadras e as reações foram diversas, desde pessoas que não sabiam se poderiam autorizar a pintura do espaço, quanto pessoas que disseram de forma hostil que chamariam a polícia. 


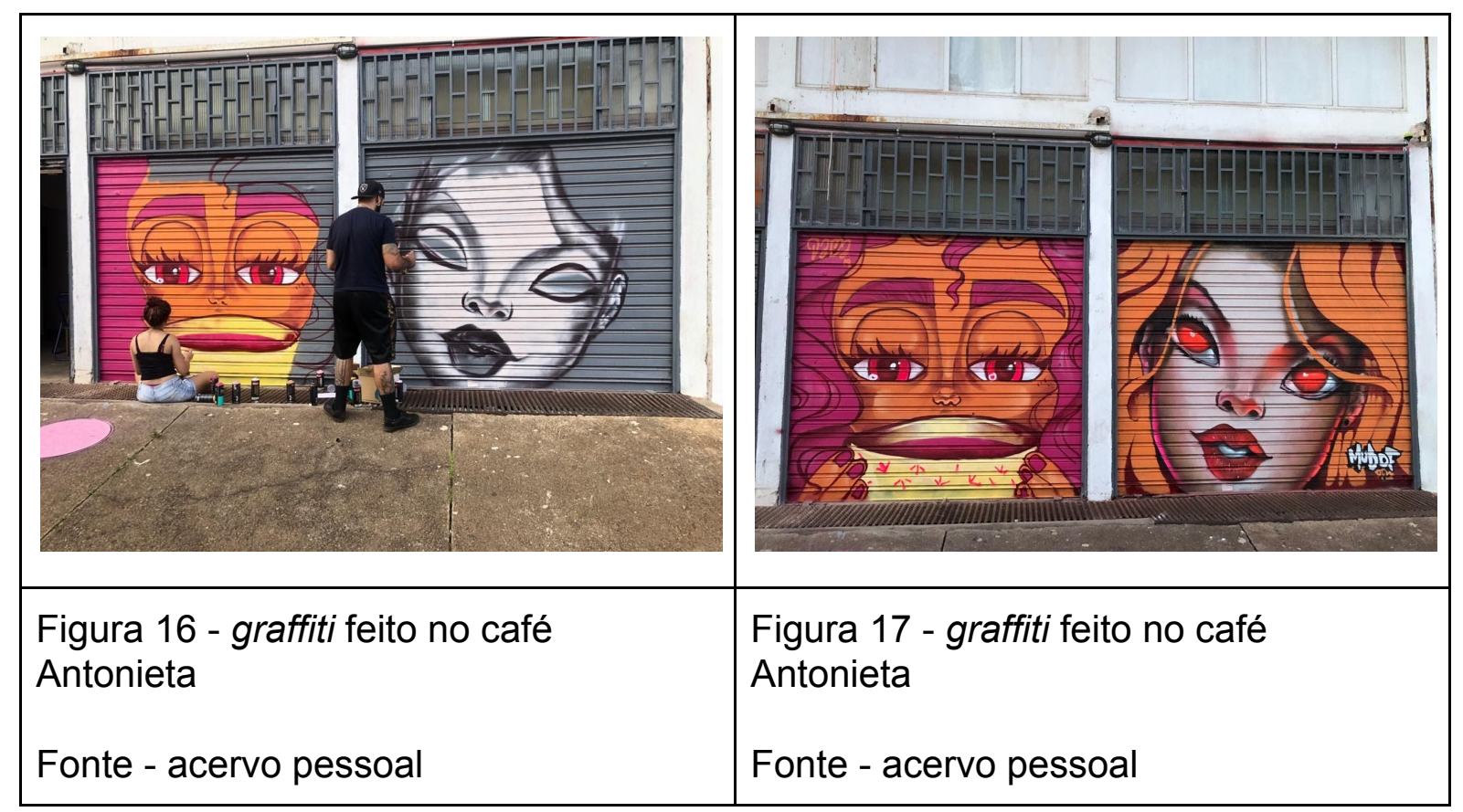

\section{Festa Seduza}

Esse graffiti foi encomendado pela Atlética de arquitetura da faculdade UniCEUB, o trabalho foi executado com um tema pré definido pelos contratantes, era necessário que a arte refletisse o símbolo do curso, que é uma medusa, e mantendo a identidade visual dos flyers do evento.

Assim que a arte foi executada a mesma foi exposta no salão de festas, a fim de compor a decoração do espaço e fazer um cenário para fotos. Esse trabalho é um exemplo de trabalho encomendado com fim decorativo que se distancia do objetivo inicial do graffiti que é transgredir, apesar de ser encomendado pelo signo que o graffiti representa não carrega seu significado original.

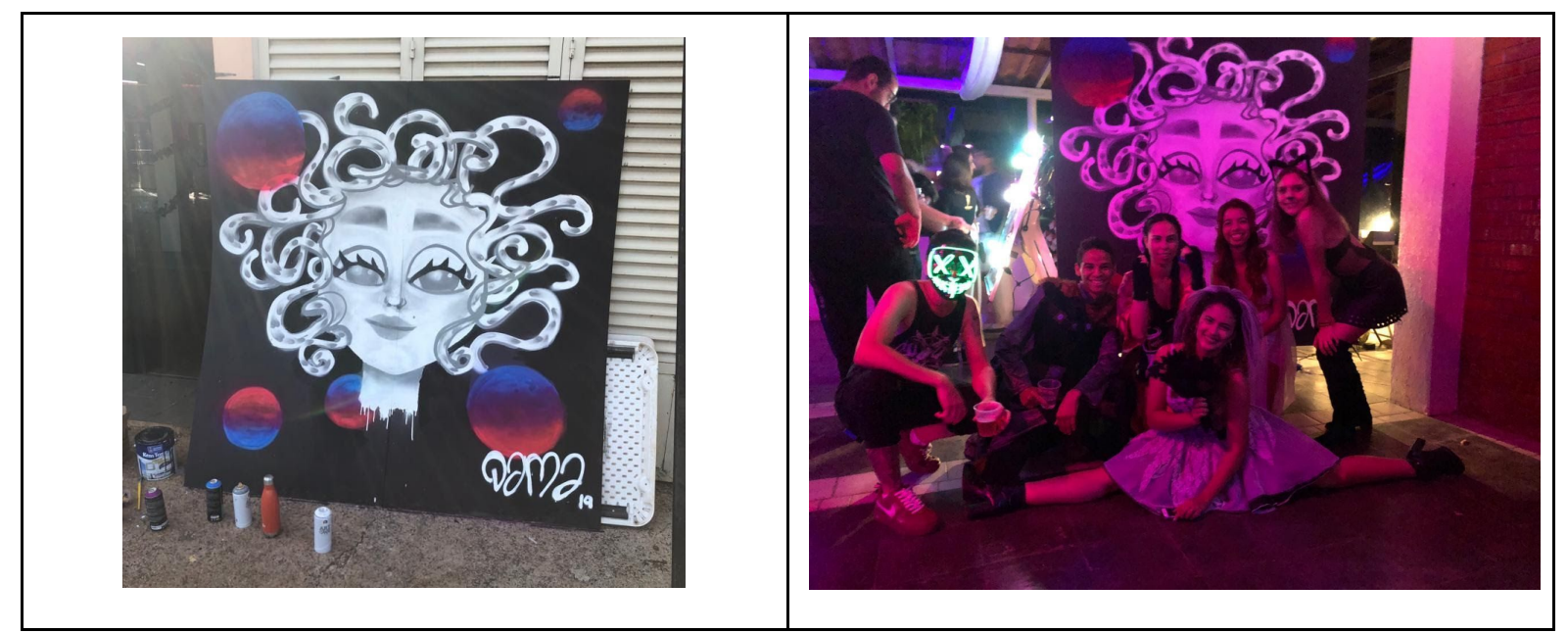


Figura 18 - Graffiti festa Seduza

Figura 19 - Graffiti festa Seduza

Fonte - acervo pessoal

Fonte - acervo pessoal

Graffiti da fachada do hospital de base

Este graffiti foi realizado no hospital de base localizado na Asa Norte e foi uma iniciativa da Rede Feminina de Brasília, uma instituição voluntária que reuniu mais de vinte artistas para renovar a fachada do hospital de base. Nesse projetos os artistas trabalharam em grupo ou individualmente, o trabalho realizado pode ser configurado como uma gentileza urbana, em que todos os artistas trabalharam voluntariamente em prol de de revitalizar a fachada do hospital.

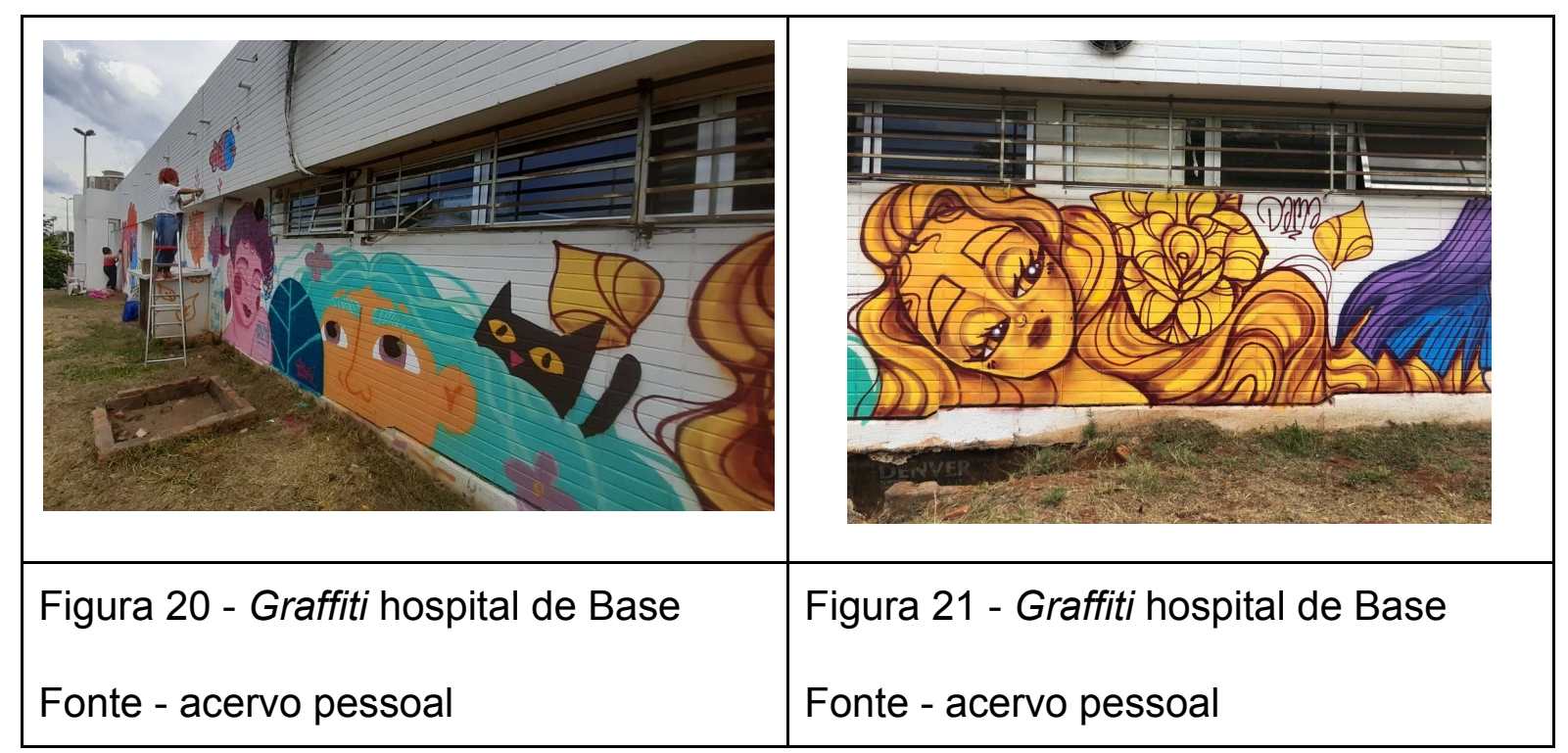

\section{Terceiro encontro de graffiti do DF}

Este graffiti foi realizado no setor comercial sul, em um evento promovido pela secretaria da cultura nos dias 02 e 03 de novembro de 2019, sendo esta a sua terceira edição - para participar do evento os artistas têm que ser aprovados pelo edital lançado pela secretaria da cultura anualmente. Foram selecionados 60 artistas que pintaram o Beco do Rato oficialmente, mas além desses 60 artistas foram mais grafiteiros que não foram contemplados pelo edital, contudo pintaram de toda forma. 
Os artistas selecionados enviaram suas propostas individuais ou em grupo, dessa forma já tinham seu espaço garantido para a arte, contudo era recomendado que se chegasse cedo no local para que houvesse a escolha do muro de cada artista. Assim que os artistas começaram seus trabalhos emissoras de TV como a rede globo foram cobrir o evento de forma a promover os artistas e a revitalização do espaço.

O evento foi um exemplo de como o graffiti pode ser uma forma de "acupuntura urbana", os artistas foram chamados para revitalizar o lugar que já foi conhecido como a "cracolândia de brasília", com as artes realizadas o lugar se tornou mais convidativo ao cidadão.

Entretanto para os artistas a motivação não era apenas de revitalizar o lugar, boa parte dos grafiteiros além do trabalho oficial que foram chamados para fazer, estes também fizeram outras intervenções urbanas com o intuito de ocupar o máximo possível o beco com seus nomes artísticos, que também são chamados pelos artistas de "vulgo", sempre procurando um lugar mais alto com mais visibilidade. Os grafiteiros nesses eventos aproveitam também para enaltecer uns aos outros trocando assinaturas em seus "black books" (figura x), que são livros destinados para grafiteiros trocarem seus trabalhos, além disso os artistas também trocam adesivos das suas artes.

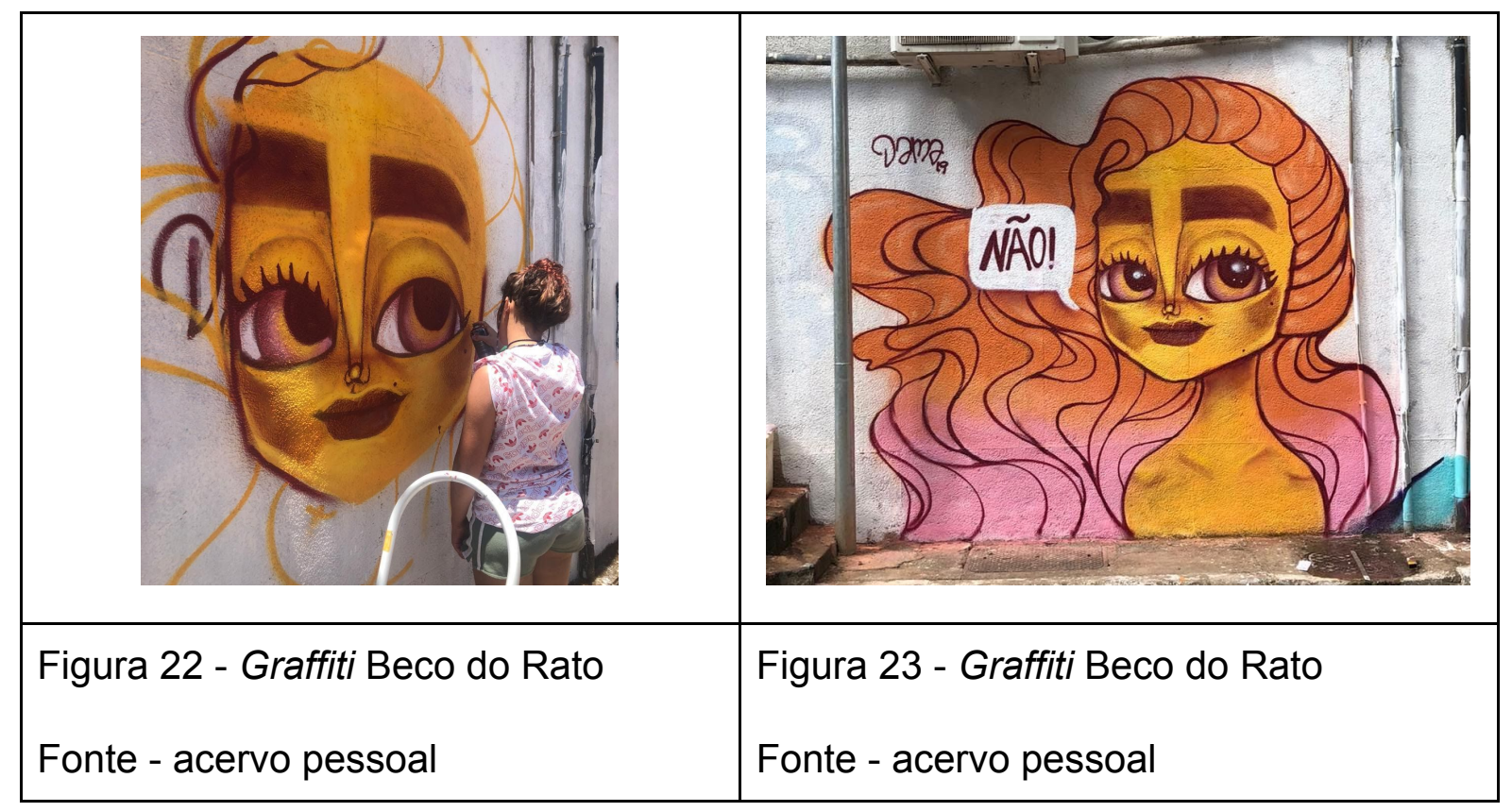




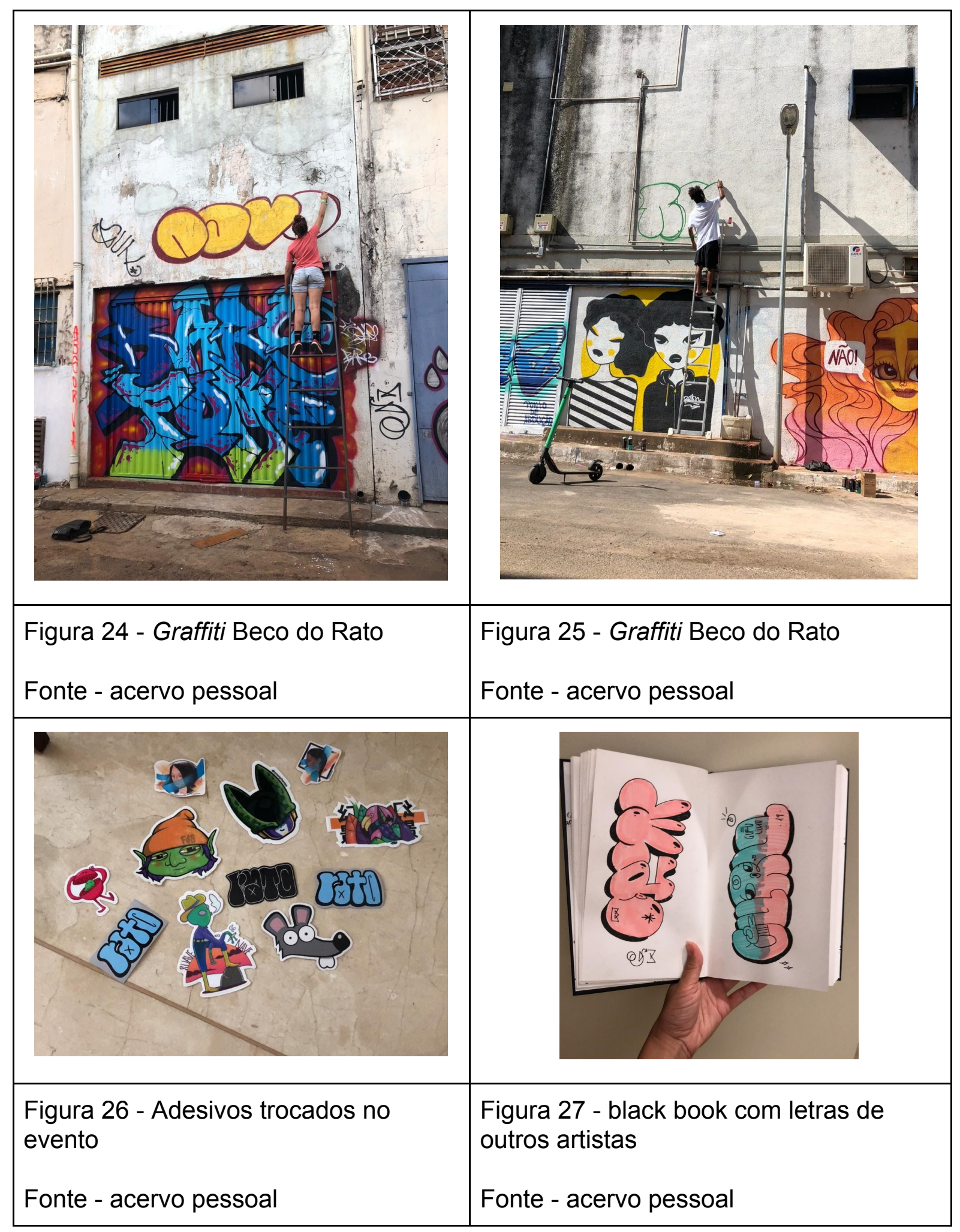




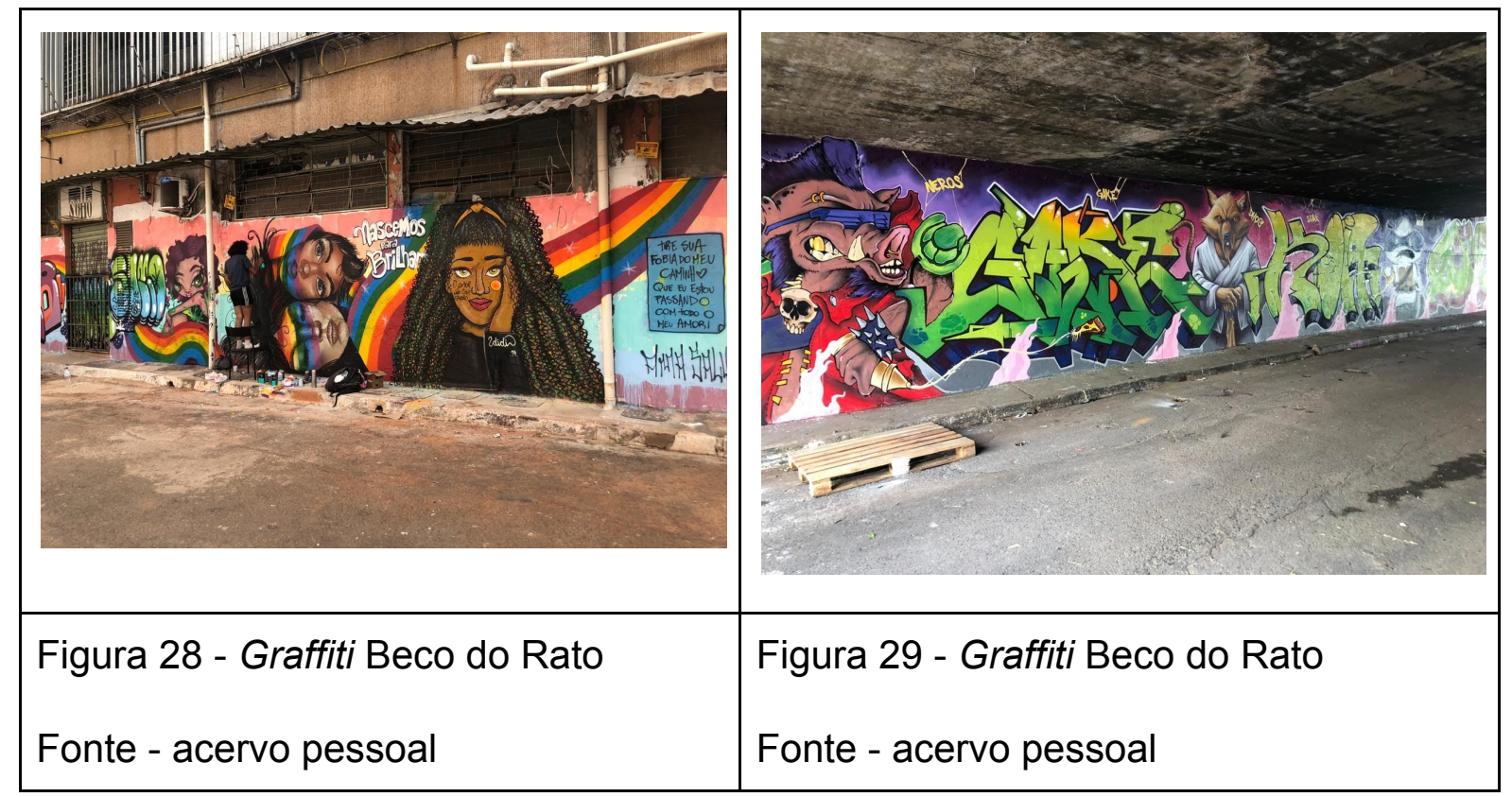

\subsection{Análise das respostas do questionário}

Devido a pandemia do coronavírus as respostas do questionário foram todas coletadas por meio google forms por um link compartilhável totalizando 86 respostas sendo 34 homens e 41 mulheres que serão preservadas as identidades de cada entrevistado, sendo a faixa etária predominante das respostas de 18 a 35 anos, seguido por 36 a 50 anos. Cabe especificar, ainda, que por considerações a questões éticas de pesquisa, os nomes dos entrevistados que responderam questões abertas do questionário enviado, foram resguardados quando citados neste trabalho.

\begin{tabular}{|c|c|}
\hline$\frac{\text { Homenens }}{4553 \%}$ & $\begin{array}{l}\text { - Até } 17 \text { anos } \\
\text { De } 18 \text { a } 35 \text { anos } \\
\text { De } 36 \text { a } 50 \text { anos } \\
\text { De } 51 \text { a } 65 \text { anos } \\
\text { - A partir de } 66 \text { anos }\end{array}$ \\
\hline $\begin{array}{l}\text { Figura } 30 \text { - Gráfico de proporção de } \\
\text { homens e mulheres }\end{array}$ & $\begin{array}{l}\text { Figura } 31 \text { - Gráfico de proporção de } \\
\text { faixa etária }\end{array}$ \\
\hline
\end{tabular}


As cidades que tiveram mais pessoas que responderam o questionário foram Brasília, seguido por São Paulo e DF.

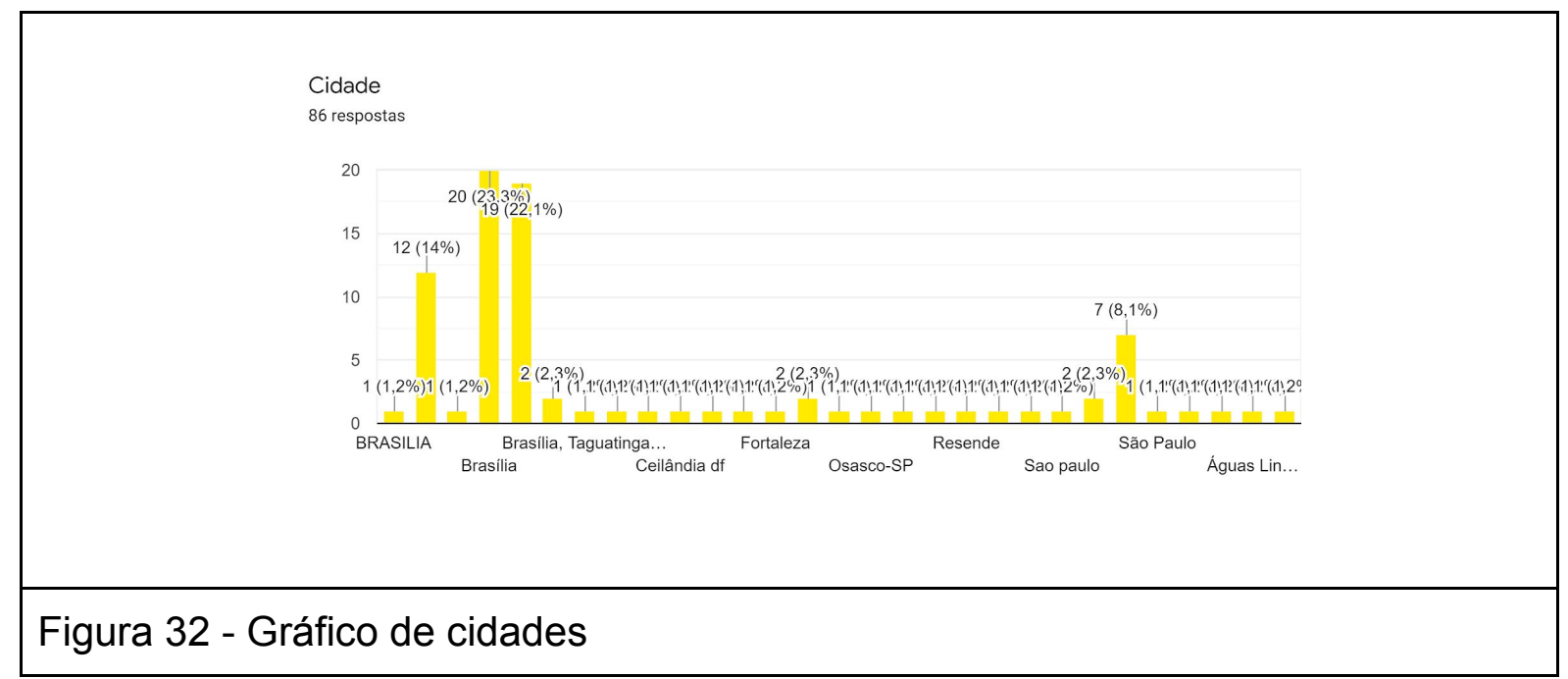

A primeira pergunta foi referente ao espaço urbano, se as pessoas questionadas percebiam as intervenções urbanas em seu caminho, sendo oitenta e uma respostas afirmativas e cinco negativas, destacou-se entre as respostas da pergunta "Qual tipo de intervenções artísticas você se lembra ter visto? Alguma delas te chamou mais atenção?" (Figura 33), graffiti, pixação, lambe- lambe, foram algumas das respostas dadas como "Graffiti, pixação, lambe-lambe. A última que chamou atenção foi um lambe lambe perto da rodoviária escrito "A arte salva" (Entrevistado 83, setembro de 2020) e também "Grafites nas tesourinhas de Brasília" (Entrevistado 31, setembro de 2020).

1- Ao percorrer a cidade, você percebe intervenções urbanas artísticas presentes em seu caminho?

86 respostas

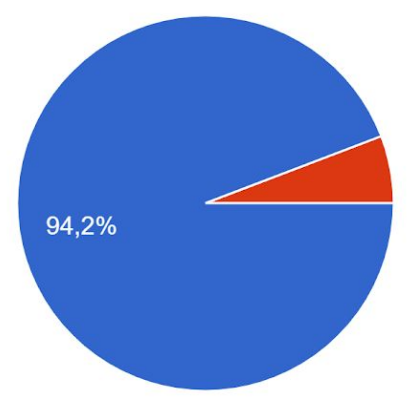


Figura 33 - Gráfico de proporção entre pessoas que percebem ou não intervenções artísticas em seu caminho

Quando questionados sobre qual seria a motivação de um artista para pintar no espaço público o grupo de grafiteiros tiveram as respostas variadas desde ocupar o espaço a ter acesso a um público variado, e quatro respostas relacionadas ao embelezamento da cidade como "As motivações são várias e subjetivas. Entre elas: se expressar, se divertir, deixar um espaço mais bonito, chamar atenção pra alguma ideia, etc." (Entrevistado 83, setembro de 2020).

Já o grupo de pessoas que apenas observam os graffitis em sua maioria deram respostas relacionadas ao embelezamento ou alteração do espaço urbano de forma positiva da cidade como "Creio que a estrutura da cidade em si, ter uma decoração mais bonita e trazer mais arte pra cidade." (Entrevistado 4, setembro de 2020) e "Revitalização para um espaço da cidade." (Entrevistado 8, setembro de 2020) totalizando dezoito respostas, seguido por respostas relacionadas a expressão do artista como "Liberdade de expressão" (Entrevistado 5, setembro de 2020) e "A necessidade de se expressar" (Entrevistado 1, setembro de 2020) totalizando dez respostas. É possível observar mediante as respostas deste grupo que a maioria das pessoas veem o trabalho do artista urbano como uma gentileza urbana e como um meio do artista se expressar.

Quanto ao grupo de pessoas que já encomendaram graffitis para seu espaço privado as respostas foram relacionadas a reflexão, mensagem e apropriação como "Para trazer reflexões para a sociedade" (Entrevistado 56, setembro de 2020).

A as respostas dos três grupos foram parecidas apesar de que o grupo de grafiteiros evidenciaram mais a motivação de intervir na rua com um meio de expressão e ocupação e já o grupo de pessoas que observam os graffitis obtiveram mais respostas que evidenciam o trabalho do artista urbano como uma gentileza urbana.

Quando questionados sobre qual seria a motivação de um artista para pintar no espaço privado o grupo de grafiteiros deram respostas quase em totalidade relacionadas ao ganho financeiro, com nove respostas como "Incentivo financeiro" (Entrevistado 38, em setembro de 2020). 
O grupo de pessoas que apenas observam os graffitis em sua maioria deram também respostas relacionadas a ganho financeiro totalizando dezesseis respostas como "Em um espaço privado a ideia seria embolsar dinheiro pela sua arte e dar ao local um caráter único." (Entrevistado 2, em setembro de 2020), havendo respostas relacionadas também a divulgação da arte com seis respostas, expressão do artista com quatro respostas e potencial de mudança do lugar com cinco respostas.

Já o grupo de pessoas que já encomendaram graffitis para seu espaço privado deram respostas variadas como "Divulgar sua arte" (Entrevistado 56, setembro de 2020) e "mensagem".

Referente a pixação e graffiti houveram setenta e quatro respostas afirmativas de que há diferença entre graffiti e pixação e doze negativas, e quando questionados sobre o que representaria o graffiti e a pixação podendo marcar mais de uma opção de resposta, as respostas que predominaram para qualificar graffitis foram arte,comunicação, publicidade e transgressão em ordem respectiva entre as mais votadas da maior para a menor, já para pixação as respostas mais votadas foram poluição visual, transgressão, comunicação, atividade de caráter social, crime, arte e publicidade em ordem respectiva entre as mais votadas da maior para a menor.

\begin{tabular}{|l|}
\hline $\begin{array}{l}\text { 6- Para você, existe diferença entre graffiti e pixação? } \\
86 \text { respostas }\end{array}$ \\
\hline $\begin{array}{l}\text { Figura } 34 \text { - Gráfico de proporção entre pessoas que consideram que existe ou } \\
\text { não diferença entre graffiti e pixação }\end{array}$ \\
\hline
\end{tabular}




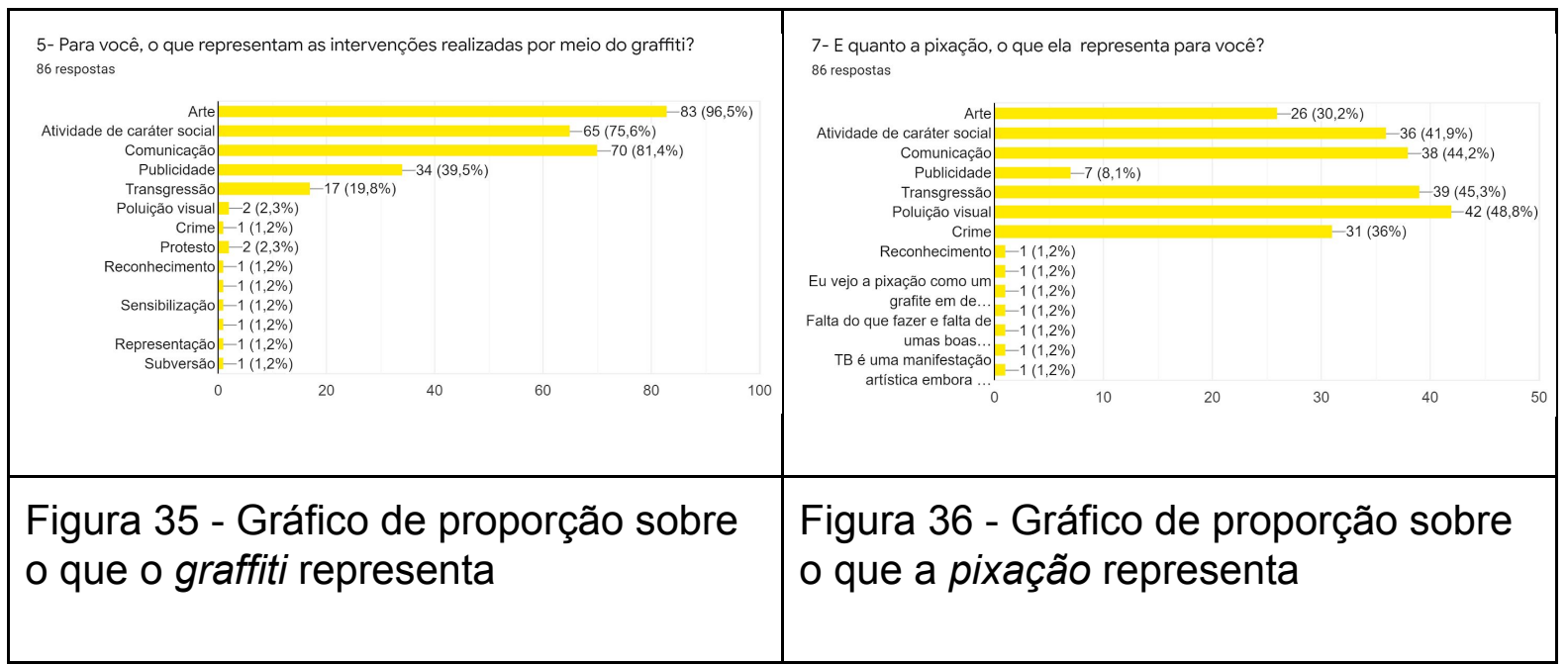

A oitava questão era referente ao espaço de exposição de obras de arte, houveram setenta e sete respostas afirmativas quanto ao valor que a agregado a arte pelo espaço que a mesma é exposta e nove respostas negativas. Após a pergunta foram feitas mais quatro perguntas relacionadas a quatro graffitis, dois feitos pela a autora para serem usados como material da pesquisa e outros dois de dois grafiteiros brasilienses as perguntas feitas foram se os graffitis teriam a mesma assimilação visual se estivesse em um lugar privado ou privado, a maioria das respostas foi que não como mostram os gráficos abaixo.

8- Você acha que o local de exposição de uma obra de arte agrega valor a ela? 86 respostas
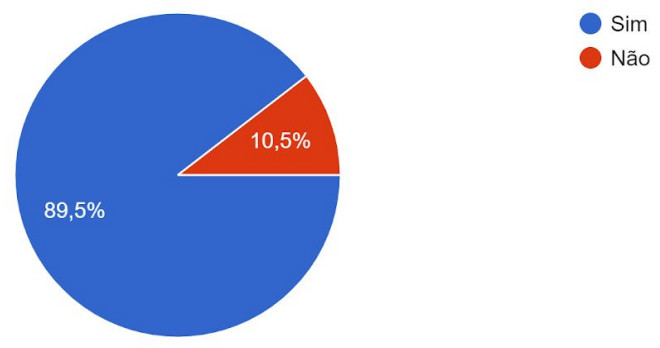

Não

Figura 37 - Gráfico de proporção entre pessoas que acham que o local da obra agrega ou não valor a mesma 


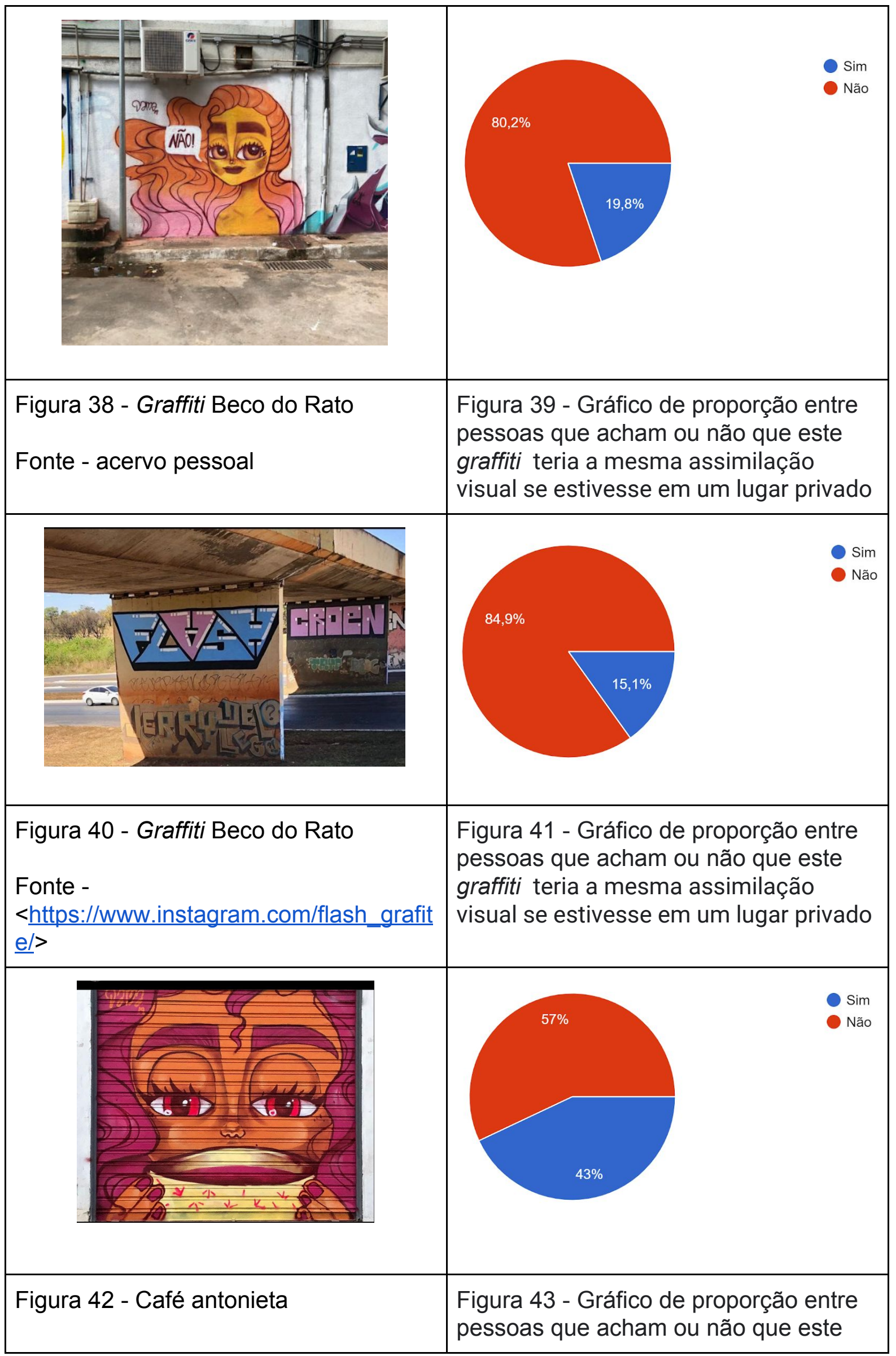




\begin{tabular}{|l|l|}
\hline Fonte - acervo pessoal & $\begin{array}{l}\text { graffiti teria a mesma assimilação } \\
\text { visual se estivesse em um lugar público }\end{array}$ \\
\hline $\begin{array}{l}\text { Figura 44 - Graffiti Beco do Rato } \\
\text { Fonte - } \\
<\text { shttps://www.instagram.com/betinhobas } \\
\text { s/> }\end{array}$ & $\begin{array}{l}\text { Figura 45 - Gráfico de proporção entre } \\
\text { pessoas que acham ou não que este } \\
\text { graffiti teria a mesma assimilação } \\
\text { visual se estivesse em um lugar público }\end{array}$ \\
\hline
\end{tabular}

Na sequência, foi feita a pergunta "qual a sua relação com grafite" separando as pessoas que responderam o questionário em três grupos: pessoas que praticam graffiti, pessoas que já encomendaram o trabalho de um grafiteiro para seu espaço privado e pessoas que apenas observam graffitis, dessa forma foi possível avaliar se os grupos tinham respostas parecidas dentro do próprio grupo ou entre os grupos.

11- Qual a sua relação com graffiti?

86 respostas

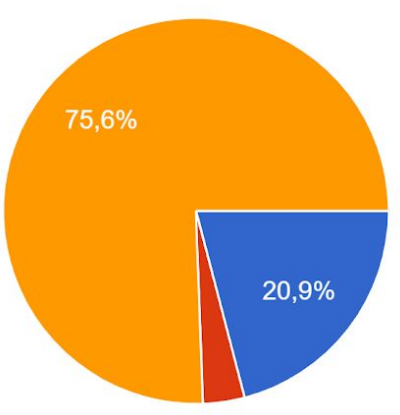

Pratico graffiti

Já encomendei o trabalho de um grafiteiro para o meu espaço privado

Apenas um observador (podendo gos ou não da pratica)

Figura 46 - Gráfico de proporção entre pessoas e sua relação com o graffiti 
$\mathrm{Na}$ sequência, foram feitas perguntas específicas para cada grupo, começando com a pergunta "Para você, o graffiti tem potencial para dar uma nova identidade ao local onde é realizado? Se sim, de que maneira?" para o grupo de pessoas que apenas observavam graffitis, que no caso englobam os outros grupos uma vez que o grafiteiro também observa os graffitis de outras pessoas por exemplo, de oitenta e seis respostas oitenta e cinco responderam que sim justificando em sua maioria que o espaço poderia ser revitalizado, modificado, embelezado e que o artista poderia passar uma mensagem com respostas como "Sim, como uma obra de arte que traz beleza e passa uma mensagem/ sentindo individual para cada um que olha." (Entrevistado 18, setembro de 2020) e "Sim,o graffiti tem o poder de revitalizar um espaço e mudá-lo" (Entrevistado 8, setembro de 2020).

O próximo grupo a responder perguntas foi o grupo que já encomendou o trabalho de um grafiteiro para seu espaço privado, que respondeu a pergunta "Você acha que o graffiti agrega valor comercial ao local? Se sim, de que maneira?" e as respostas foram "Sim, uma vez que o local fica mais atraente." (Entrevistado 61, setembro de 2020) e "A arte transforma tudo e todos." (Entrevistado 84, setembro de 2020).

Já as últimas duas perguntas foram destinadas ao grupo de pessoas que praticam graffiti, a primeira foi "Você conhece legislações em relação às intervenções realizadas por meio de graffiti ou pixação? Se sim, identifica contradições em alguma norma específica?" houveram cinco pessoas que desconheciam a legislação referente ao graffiti, outras quatro pessoas deram respostas relacionadas a lei que categoriza o graffiti como crime ambiental como podemos ver na resposta abaixo

"Sim. Na legislação fala que o Graffiti é permitido desde que com autorização, o que na prática implica que o Graffiti não é permitido, pois não existem mecanismos para conseguir autorização para pintar na maioria dos espaços públicos como viadutos, tapumes, empenas e etc. Outra característica é que a lei coloca o termo pichação de forma criminalizada e o Graffiti como forma de valorização do espaço urbano, distingue as palavras, 
mas não o que isso significaria, e deixa margem para interpretações muito amplas por parte das forças de segurança pública, que interpretam as ações e agem de acordo com seu próprio ponto de vista. Muitas vezes, em função dessa distinção, a polícia utiliza de violência para abordar aqueles que ela considera que estão "depredando" o local em questão. Por fim, é enquadrado na lei ambiental, ou seja, quem é pego grafitando sem autorização é considerado um contraventor ambiental, o que muitas vezes é ridículo se comparado com as propagandas e outdoors espalhados indiscriminadamente pelas cidades." (Entrevistado 38, setembro de 2020).

Por fim, a última pergunta foi "Você conhece incentivos públicos para intervenções realizadas por meio de graffiti? Se sim, quais?", como houveram mais grafiteiros do Distrito Federal as respostas variam entre "não" e que conheciam os editais da secretaria da cultura que promovem a cultura do graffiti além do Comitê Permanente de Graffiti

\section{Considerações finais}

Quanto às considerações finais deste trabalho salientamos primeiramente aquelas relativas às leituras de referência iniciais que tiveram rebatimento em vários aspectos nas pesquisas realizadas posteriormente pelo questionário elaborado para os três agentes dessa pesquisa que são os grafiteiros, pessoas que encomendam trabalhos de graffiti e pessoas que observam o graffiti nos espaços. O questionário foi realizado online por conta da Pandemia causada pelo novo coronavírus; cabe ressaltar que a maioria das pessoas que responderam a este questionário residem em São Paulo e Brasília, restringindo as respostas a vivência dessas cidades.

Ainda em relação ao questionário, foi possível observar que a maioria das pessoas, mais de noventa por cento percebem intervenções urbanas no seu trajeto usual, o que vai contra, de certo modo, ao que a Hannah Arendt diz sobre o espaço urbano ser incapaz de abrigar o irrelevante, uma vez que, mesmo aglomerado aos 
elementos da cidade o graffiti se destacou nas respostas dos entrevistados e foi possível observar, inclusive, respostas bem específicas sobre quais eram os graffitis observados. Dentro dessas intervenções os entrevistados responderam em sua maioria que enxergam diferenças entre graffiti e pixação, conforme constatado em uma das questões do questionário relativas ao graffiti, na qual o mesmo foi classificado, em sua maioria, como arte, comunicação, atividade de caráter social e publicidade, ao contrário da pixação, que foi considerada como poluição visual, transgressão e comunicação.

A pesquisa também permitiu constatar, a partir do público entrevistado, que o lugar de exposição da obra de arte agrega valor a mesma, o que foi reafirmado nas questões seguintes em que haviam 4 imagens de graffitis, dois em espaço público e dois em espaço privado, e em todas as questões a maioria das pessoas falou que os graffitis não teriam a mesma assimilação visual se estivessem em um lugar diferente de onde foram pintados, se o público estivesse no privado e se o privado estivesse no público.

Por fim, também a partir do questionário utilizado como instrumento da pesquisa, foram feitas perguntas específicas para cada agente, começando pelas pessoas que observam o graffiti, foi possível observar nas respostas que noventa e nove por cento das pessoas afirmaram que o graffiti tem potencial para mudar o que pode ser visto como um tipo de gentileza urbana confirmando o que foi dito posteriormente na fundamentação teórica, uma vez que todas as respostas foram positivas. A pergunta para as pessoas que encomendam o graffiti obteve respostas positivas sobre o graffiti agregar valor comercial ao local o que mostra que o graffiti não só tem um valor estético, mas é um potencializador comercial do espaço privado. Já as últimas duas perguntas foram referentes a legislação e sua relação com o grafite, a pergunta foi direcionada aos grafiteiros, que identificaram contradições na lei que criminaliza pixação mas não distingue o que seria graffiti e o que seria pixação, tornando a lei arbitrária como foi dito previamente na fundamentação teórica e também foi apontado que o graffiti ser punido por crime ambiental em uma cidade que tem vários elementos urbanos que prejudicam o meio ambiente e a vista da cidade, como propagandas seria uma contradição, já que outros elementos não são criminalizados. 
Por fim cabe ressaltar que, ao longo da pesquisa necessitou-se fazer algumas adaptações por conta da pandemia do coronavírus, como etapa do contato com o público que seria realizado inicialmente no espaço público junto a obras de graffiti. Quanto aos objetivos da pesquisa, salienta-se aqui como foram atendidos. $O$ objetivo geral, vinculado a "Realizar uma pesquisa comparativa sobre a percepção de distintos grupos de indivíduos em relação às intervenções realizadas no espaço público e privado por meio das expressões em graffiti”, foi alcançado por meio referencial bibliográfico adotado e questionário realizado com grupo pertinente, a partir do qual pôde-se comparar as percepções sobre graffiti entre os três agentes em um grupo de 86 pessoas. Assim como os objetivos específicos,a saber: o primeiro objetivo vinculado a construção de um banco de imagens sobre graffiti no exterior e no Brasil que foi alcançado por pesquisa de imagens pela autora e produção de graffitis pela autora que também foram anexados a pesquisa; o segundo objetivo vinculado a criação de um banco de dados sobre a percepção do graffiti por grupos distintos de atores a partir do questionário foi atingido plenamente e o terceiro objetivo foi atingindo parcialmente, a programação era de realizar 4 graffitis, mas só foi possível realizar dois por conta da pandemia que nos levou a todos ao confinamento social desde março de 2020 até o presente momento.

Espera-se que essa pesquisa contribua futuramente para a elaboração de novos trabalhos acadêmicos, que possa contribuir com a cultura do graffiti e sua comunidade e que tenha ampliado a voz de grafiteiros e grafiteiras.

\section{Bibliografia}

ARGAN, Giulio Carlo. História da arte como história da cidade. São Paulo: Martins Fontes, 2005.

ARENDT, Hannah. A condição humana. Rio de Janeiro: Forense Universitária, 2007.

BAUMAN,Zygmunt. Globalização e as consequencias humanas. Tradução Marcus Penchel. Rio de Janeiro: Jorge Zahar Ed., 1999.

BAUMAN,Zygmunt. Tempos líquidos. Tradução: Carlos Alberto Medeiros. Rio de Janeiro: Jorge Zahar Ed., 2007. 
CAMPOS, Ricardo. Pintando a cidade. Uma abordagem antropológica ao graffiti urbano. Dissertação (Doutorado em Antropologia Visual) - Universidade Aberta, Lisboa, 2007.

CANEVACCI, Massimo. A cidade polifônica: ensaio sobre a antropologia da comunicação urbana. 2. ed. São Paulo: Studio Nobel.

COELHO, Gustavo. PIXAÇÃO COMO TRABALHO DE CONCLUSÃO DE CURSO (TCC): CORAJOSOS INVESTIMENTOS FILOSÓFICOS PARA O ENSINO DA ARTE. UERJ, 2009

DEBORD, Guy. A Sociedade do Espetáculo.Railton Sousa Guedes Coletivo Periferia, 2003.

GASKELL, G.; BAUER, M. W. Pesquisa Qualitativa com Texto Imagem e Som: um manual prático. Apud: FARR, R. M. (1982) Interviewing: the Social Psychology of the Interview. 2. ed. Petrópolis - RJ: Editora Vozes, p.80-85, 2003.

JACQUES, Paola Berenstein. Breve histórico da Internacional Situacionista - IS. Arquitextos, São Paulo, ano 03, n. 035.05, Vitruvius, abr. 2003 <https://www.vitruvius.com.br/revistas/read/arquitextos/03.035/696>.

LERNER, Jaime. Acupuntura Urbana. 5. ed. Rio de Janeiro: Record, 2011.

Lei n. 12.408, de 25 de maio de 2011.

Art.65 da Lei n. 9.605, de 12 de fevereiro de 1998.

MAGON, Rafael. Lá de baixo, 8 julho 2019. Disponível em:

$<$ https://www.youtube.com/watch?v=MaiL2_HU8J0>

MANGUEL, Alberto. Lendo imagens: uma história de amor e ódio. Tradução de Rubens Figueiredo, Rosaura Eichemberg, Cláudia Strauch. São Paulo: Companhia das letras 2001.

MESQUITA, Marcelo, VALIENGO, Guilherme. Cidade Cinza. 2011. Disponível em: $<$ https://www.youtube.com/watch?v=svFLNSQevag\&t=4s> Acesso 1 de março de 2020 às $17: 40$. 
MIGUEZ, Luiza. Edição 78, março 2013. Disponível em:

$<$ https://piaui.folha.uol.com.br/materia/grafite-da-discordia/>

OLIVEIRA, Roberto T., WAINER, João. Pixo. 2010. Disponível em:

$<$ https://www.youtube.com/watch?v=skGyFowTzew\&t=542s\&has_verified=1>

PAULO, Paula Paiva. Justiça de SP condena Doria e a Prefeitura por remoção de grafites na 23 de Maio. Disponível em:

$<$ http://g1.globo.com/sp/sao-paulo/noticia/2019/02/26/justica-de-sp-condena-doria-ea-prefeitura-por-remocao-de-grafites-na-23-de-maio.ghtml> Acesso 23 de out de 2019 às 07:11.

QUEIROZ, Christina. Edição 269, jul 2018. Disponível em:

$<$ http://revistapesquisa.fapesp.br/2018/07/04/entre-transgressao-e-arte/>

QUEMIN, Alain, Ana Letícia Fialho, Angélica de Moraes. O valor da obra de arte. São Paulo: Metalivros, 2014.

SANTIAGO, Tatiana.Doria sanciona lei que penaliza pichadores com multa.

Disponível em:

$<$ https://g1.globo.com/sao-paulo/noticia/doria-sanciona-lei-que-penaliza-pichadorescom-multa.ghtml>

acesso 23 de out de 2019 às 07:11

SILVER, Tony. Style Wars. 1983.Disponível em:

$<$ https://www.youtube.com/watch?v=f9KxbaSU-Eo>

TOMAZ, Kleber. Após invasão em 2008, pichadores são convidados a voltar à Bienal. 2010, Disponível em: < http://glo.bo/1TIKXF4 >

WISNIK, Guilherme, Julio Mariutti.Espaço em obra: cidade, arte, arquitetura. São Paulo: Edições Sesc São Paulo, 2018. 